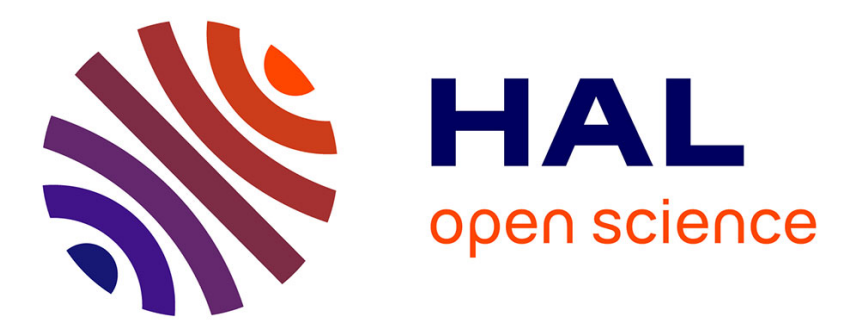

\title{
Symbolism among the last hunterefisheregatherers in northern Iberia: Personal ornaments from El Mazo and El Toral III Mesolithic shell midden sites
}

Solange Rigaud, I Gutierrez-Zugasti

\section{- To cite this version:}

Solange Rigaud, I Gutierrez-Zugasti. Symbolism among the last hunterefisheregatherers in northern Iberia: Personal ornaments from El Mazo and El Toral III Mesolithic shell midden sites. Quaternary International, 2016, 10.1016/j.quaint.2015.10.029 . hal-03020923

\section{HAL Id: hal-03020923 \\ https://hal.science/hal-03020923}

Submitted on 12 Oct 2021

HAL is a multi-disciplinary open access archive for the deposit and dissemination of scientific research documents, whether they are published or not. The documents may come from teaching and research institutions in France or abroad, or from public or private research centers.
L'archive ouverte pluridisciplinaire HAL, est destinée au dépôt et à la diffusion de documents scientifiques de niveau recherche, publiés ou non, émanant des établissements d'enseignement et de recherche français ou étrangers, des laboratoires publics ou privés. 


\title{
Symbolism among the last hunterefisheregatherers in northern Iberia: Personal ornaments from El Mazo and El Toral III Mesolithic shell midden sites
}

\author{
S. Rigaud ${ }^{\text {a, b, }}{ }^{*}$, I. Gutierrez-Zugasti \\ ${ }^{a}$ CNRS-UMI 3199 CIRHUS, New York University, 4 Washington Square North, New York, NY 10003, USA bepartment of Anthropology, New York \\ University, New York, NY 10003, USA c Instituto Internacional de Investigaciones Prehistoricas de Cantabria, Universidad de Cantabria, Ed. Interfacultativo, \\ Avda. de los Castros s/n, 39005 Santander, Cantabria, Spain
}

\begin{abstract}
L. obtusata and Trivia sp. shells were systematically used for personal ornamentation by groups who occupied northern Iberia during the Mesolithic. The shells from El Mazo and El Toral III (Asturias, Spain) offer a unique opportunity for investigating raw material procurement, selection strategies, and manufacture processes developed by Asturian Mesolithic societies for beads production. By combining taphonomic, morphometric, and microscopic analyses, our results show that the shells were introduced and transformed in the caves. Mollusk consumption at the sites and bead manufacture indicate that the sites were occupied for both economic and symbolic purposes. The use of similar shell beads by contemporaneous societies located in different environments (coastal and interior) and relying on drastically different subsistence strategies mirrors the complex circulation network developed by Mesolithic foraging societies.
\end{abstract}

\section{Introduction}

The study of littoral adaptations among past foraging societies has become a frequent topic of archaeological investigations over the past 10 years (Meehan, 1983; Cunha et al., 2002; Bartosiewicz et al., 2010; Marean, 2014; Rick et al., 2014). The development of marine and estuarine economies is seen as a major technical, social and cultural adaptation of past human societies (Binford, 1968; Erlandson, 2001; Bicho and Haws, 2008; Balbo et al., 2011; Colonese et al., 2011). Ethnoarchaeological studies have highlighted many different regional cultural trajectories among the coastal foraging communities (Ambrose, 1967; Andersen, 2000; Thompson et al., 2004; Sealy, 2006; Clune and Harrison, 2009;

Biagi, 2013).

Along the Cantabrian coast (northern Iberia), systematic coastal exploitation by hunterefisheregatherer societies is attested from the Upper Paleolithic (Madariaga de la Campa and Fernandez Pato, 
1985; Ortea, 1986; Gutierrez-Zugasti et al., 2013a ) and culminated in the central part of the region with the development of the Asturian Mesolithic, characterized by the abundance of shell middens located in rockshelters and caves, and the appearance of characteristic cobble picks termed "Asturian picks" (GonzalesMorales, 1982; Clark, 1983). Diet of the Asturian populations has been investigated and characterized as based on the collection of a variety of marine mollusks, but mainly focused on limpets (Patella depressa and P. vulgata), topshells (Phorcus lineatus) and mussels (Mytilus galloprovincialis) (GutierrezZugasti, 2009 ). Marine fishes, crustaceans and echinoderms were also collected and consumed (Gutierrez-Zugasti, 2009; Fano et al., $2013 \quad$ ). Marine resources were complemented with terrestrial mammal preys, including cervids and wild boar (Gutierrez-Zugasti et al., 2011; Marín-Arroyo, 2013 ).

Richness of food remains is counter balanced by the scarcity of lithic and bone industries, leading to some scholars to interpret the Asturian shell middens as task specific areas closely linked to inland sites (Straus, 1979; Clark, 2004) and, more recently, to open-air habitation areas located in front of the rockshelters that remain almost unknown (Arias et al., 2015). However, evidence from Mazaculos II (Gonzales-Morales et al., 1980) and from El Toral III and El Mazo (Gutierrez-Zugasti et al., 2011, 2014; Noval Fonseca, 2014), have identified archaeological structures, such as living floors, hearths and post holes inside the shell middens (as well as remains derived from diverse subsistence activities), interactions that occurred among segmented foraging societies at the end of the Mesolithic.

It has recently been shown that personal ornaments analysis can contribute in the identification of the territorial organization of societies (Komso and Vukosavljevic, 2011; Rigaud et al., 2014). The presence of this category of artifact at Asturian sites offers new insights on another aspect of the material culture disconnected from the economic activities conducted at the shell middens. In this paper, we aim to determine how coastal adaptation led Mesolithic societies to adopt specific raw material and techniques for the manufacture and use of their personal ornaments. To do so, we study the taxonomy, morphometry, technology and use-wear of several personal ornaments discovered at two Asturian shell middens, El Mazo and El Toral III, and then discuss the organization of the manufacturing process and how this data fit in the regional and European contexts.

\section{El Mazo and El Toral: location, description and stratigraphy}

El Mazo and El Toral III caves are located in the town of Andrín, belonging to the Council of Llanes, in East Asturias, Spain. The current distance from the sites to the coastline is respectively around $700 \mathrm{~m}$ and 1.4

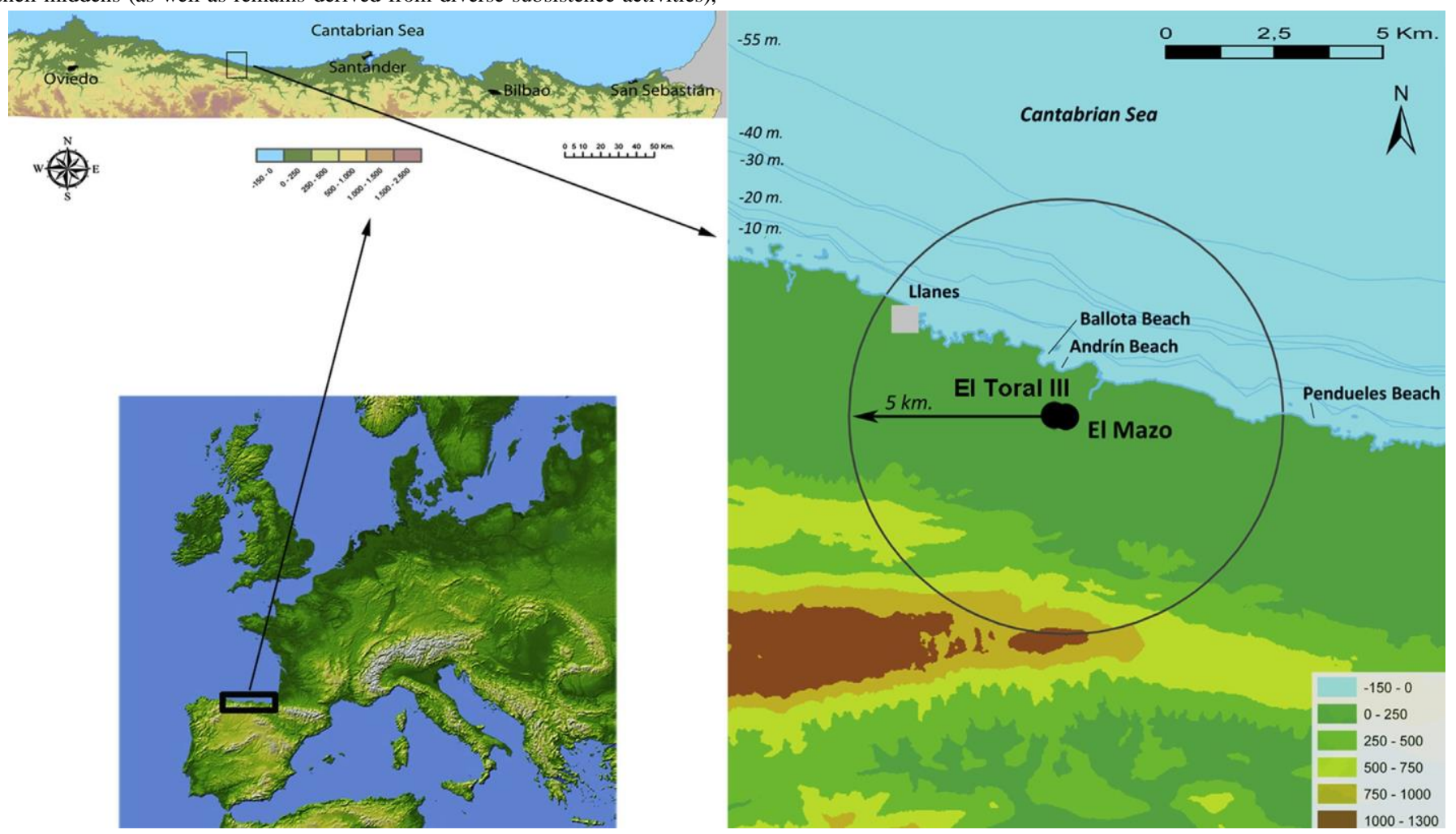

Fig. 1. Location of the Mesolithic sites of El Mazo and El Toral III.

characterizing them as residential sites. The settlement patterns show that Asturian sites are located less than $5 \mathrm{~km}$ from the coastline (Bailey and Craighead, 2003). Paralleling the development of the Asturian coastal societies, the presence of contemporaneous foraging communities in the inland mountainous area is attested (Arias, 2005e2006). The two populations developed specific economic and technical features, linked to the adoption of drastically different diets. The Asturian coastal population produced the shell middens and subsisted on a mixed terrestrialemarine diet while the inland population was focused on terrestrial resources (Arias, 2005e2006). Presence of two distinct foraging populations, which relied on contrasted systems of subsistence and coexisted in a limited area of Northern Spain, provides an opportunity to explore $\mathrm{km}$. During the Mesolithic, this distance would have varied due to the rise in sea level. However, in the last 9000 years, this distance did not exceed $5 \mathrm{~km}$ (Fig. 1).

El Mazo rockshelter extends approximately $18 \mathrm{~m}$ long and $7 \mathrm{~m}$ deep. Two test pits were performed in the inner area of the rockshelter and also in the outer platform during 2009 and 2010 (Fig. 2). Two square meters were excavated in the inner area of the rockshelter (squares V15 and V16) and all the sediment was sieved (4 and $2 \mathrm{~mm}$ meshes). Six major stratigraphic units (SUs) were identified corresponding to shell midden deposits: SUs 100/101, $102,103,104,105,106$ and 107. Some of these units included minor units or depositional events that were identified on the profiles at the end of the campaign 2010. Unit 100/101 was formed by two different layers. Units 102 and 106 were composed by archaeological material mixed with carbonate, 
while Unit 104 was a hearth. Unit 103 included also unit 112, and unit 105 included two additional units: 113 and 120. Finally, Unit 107 was formed by units of similar chronology $(110,111,114$ and 115) identified in subsequent campaigns (see Gutierrez-Zugasti et al., 2013a,b; Guti errez-Zugasti et al.,
2014). Radiocarbon dates and archaeological material place the formation of the shell midden during the Mesolithic

(Table 1).

\section{El Mazo}

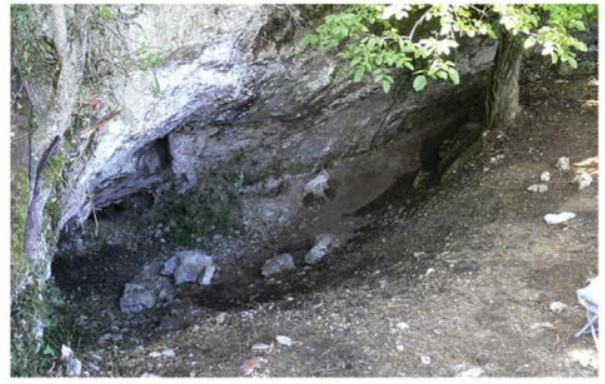

A
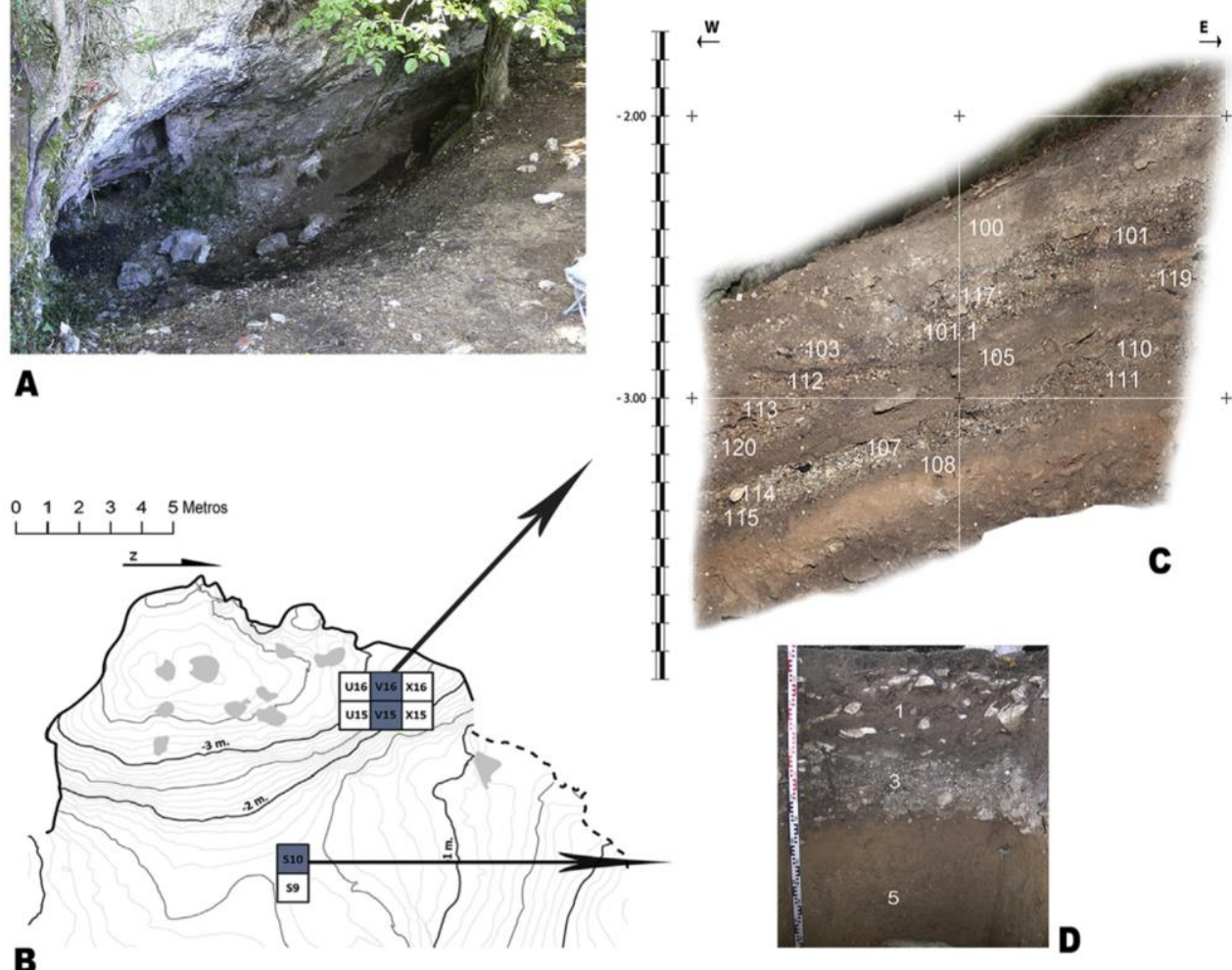

\section{El Toral III}

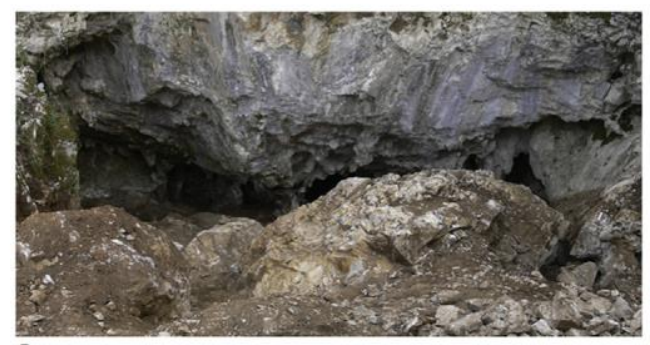

A
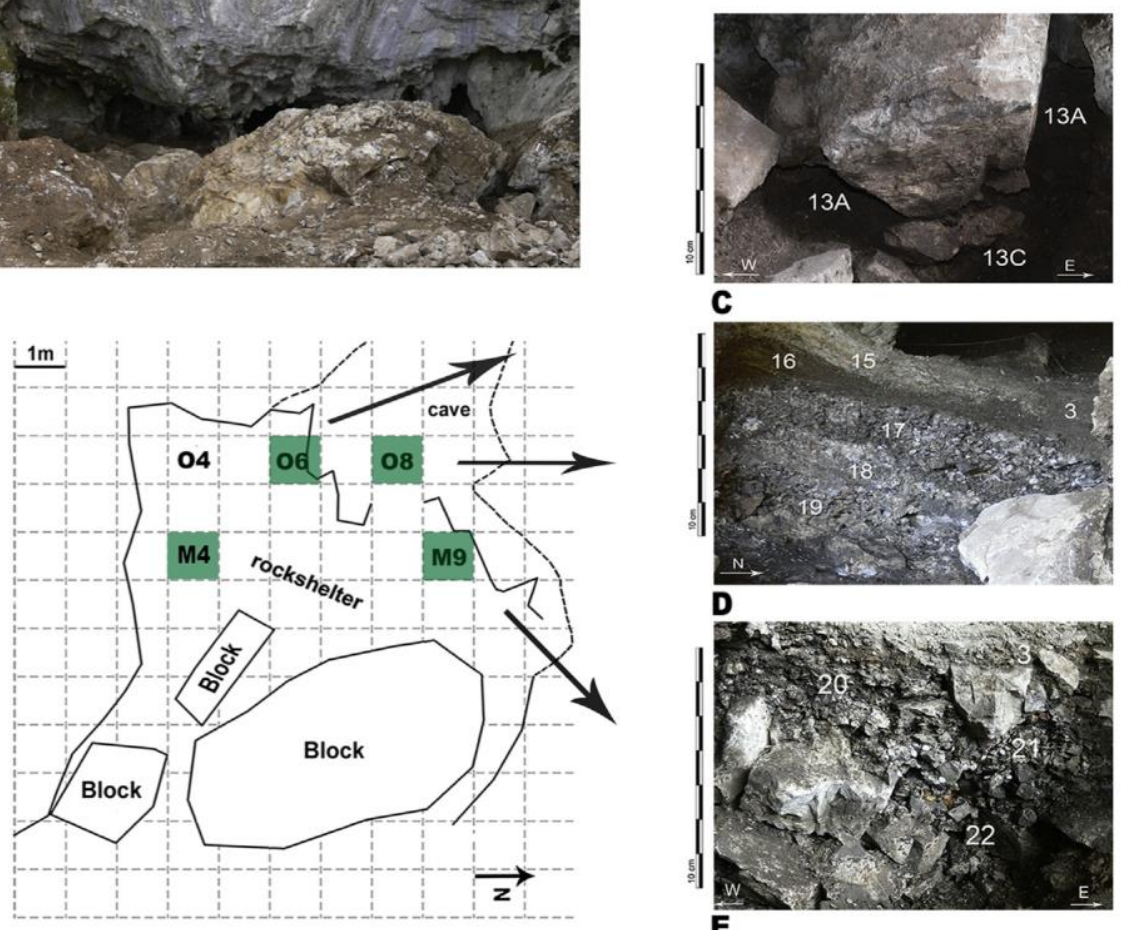

B

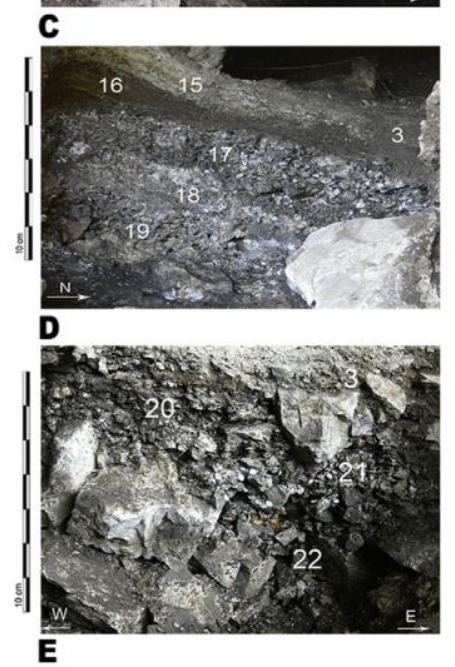




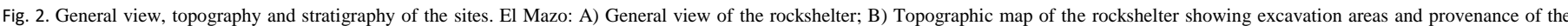

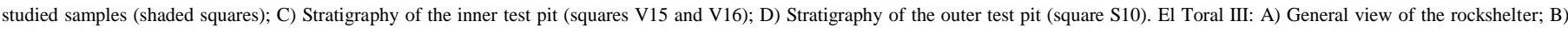

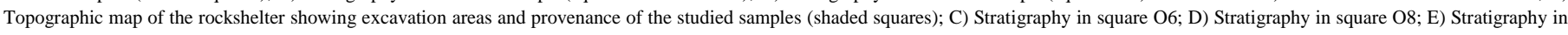
square M9.

Table 1

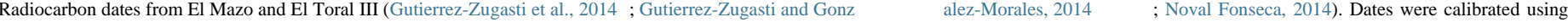
IntCal13 calibration curve (calibration program Oxcal 4.2, Reimer et al., 2013).

\begin{tabular}{|c|c|c|c|c|c|c|c|c|}
\hline \multirow{2}{*}{$\begin{array}{l}\text { Site } \\
\text { El Mazo }\end{array}$} & \multirow{2}{*}{$\frac{\text { SU }}{100}$} & \multirow{2}{*}{$\begin{array}{l}\text { Lab ref } \\
\text { OxA-28397 }\end{array}$} & \multirow{2}{*}{$\begin{array}{l}\text { Date BP } \\
6772 \pm 37\end{array}$} & \multicolumn{2}{|c|}{ Interval cal BP } & \multirow{2}{*}{$\begin{array}{l}\text { Median cal BP } \\
7624\end{array}$} & \multirow{2}{*}{$\begin{array}{l}\text { Material } \\
\text { Bone }\end{array}$} & \multirow{2}{*}{$\begin{array}{l}\text { Method } \\
\text { C14 AMS }\end{array}$} \\
\hline & & & & 7674 & 7576 & & & \\
\hline El Mazo & 101 & OxA-28389 & $7230 \pm 36$ & 8160 & 7971 & 8039 & Bone & C14 AMS \\
\hline El Mazo & 112 & OxA-28401 & $7294 \pm 37$ & 8176 & 8021 & 8102 & Bone & C14 AMS \\
\hline El Mazo & 105 & UGAMS-5408 & $7640 \pm 30$ & 8517 & 8384 & 8423 & Charcoal & C14 AMS \\
\hline El Mazo & 114 & OxA-27969 & $7990 \pm 38$ & 9006 & 8662 & 8869 & Bone & C14 AMS \\
\hline El Toral III & 17 & UGAMS-5403 & $6430 \pm 30$ & 7424 & 7289 & 7363 & Charcoal & C14 AMS \\
\hline El Toral III & 21 & UGAMS-5401 & $6750 \pm 30$ & 7662 & 7573 & 7607 & Charcoal & C14 AMS \\
\hline El Toral III & 21 & UGAMS-5400 & $7080 \pm 30$ & 7782 & 7615 & 7690 & Human bone & C14 AMS \\
\hline El Toral III & 22 & UGAMS-5402 & $6810 \pm 30$ & 7685 & 7592 & 7644 & Charcoal & C14 AMS \\
\hline El Toral III & $13 \mathrm{~A}$ & ICA-0802 & $7000 \pm 40$ & 7935 & 7735 & 7839 & Bone & C14 AMS \\
\hline El Toral III & $13 \mathrm{C}$ & UGAMS-5404 & $8550 \pm 30$ & 9548 & 9493 & 9530 & Charcoal & C14 AMS \\
\hline El Toral III & 10 & UGAMS-5405 & $8400 \pm 30$ & 9495 & 9310 & 9445 & Charcoal & C14 AMS \\
\hline
\end{tabular}

El Toral III rockshelter was almost entirely dug in a rescue excavation in

Scaphopoda, Gasteropoda, Bivalvia.) followed by an examination of the number

\begin{tabular}{|c|c|c|c|c|c|}
\hline Species & $\mathrm{N}$ & Attribution & Collection location & Site & References \\
\hline Littorina obtusata & 58 & Modern & Noirmoutier, France & Souzeaux & Vanhaeren, 2002, 2010 \\
\hline Littorina obtusata & 270 & Modern & Noirmoutier, France & Bonhomme & Vanhaeren, 2002, 2010 \\
\hline Littorina obtusata & 100 & Modern & Santander, Spain & La Concha & Alvarez-Fern andez, 2006 \\
\hline Littorina obtusata & 100 & Modern & Santander, Spain & La Maruca, & Alvarez-Fern andez, 2006 \\
\hline Littorina obtusata & 7 & Upper Magdalenian & Guipúzcoa, Spain & Urtiaga $\mathrm{E}$ & Rigaud et al., 2014 \\
\hline Littorina obtusata & 43 & Lower Magdalenian & Guipúzcoa, Spain & Urtiaga F & Rigaud et al., 2014 \\
\hline Trivia sp. & 100 & Modern & Lugo, Spain & Las Cubelas & Alvarez-Fern \\
\hline Trivia sp. & 61 & Mesolithic & Arangas, Spain & Los Canes II & Alvarez-Fern \\
\hline
\end{tabular}

2009. The excavated surface was divided in two areas, one located in the south of the cavity, area A, and one in the north, area B (Fig. 2). Area A has a succession of clay and shell midden layers and during the excavations, several stratigraphic units $(4,6,8,9,10,13 \mathrm{~A}, 13 \mathrm{~B}, 13 \mathrm{C}$ and 14) were identified as not disturbed by any post depositional processes. Area B was better preserved and was composed of several shell midden units (SUs 16 to 22). Sediments were also sieved using 4 and $2 \mathrm{~mm}$ mesh screens. Radiocarbon dates attribute units 10 and $13 \mathrm{C}$ to an early phase of the Mesolithic and units 13A,17, 21 and 22 to a more advanced phase of the Mesolithic (Table 1).

\section{Materials and methods}

\subsection{Materials}

Perforated shells from El Mazo and El Toral III were isolated during the archaeomalacological study (Bello-Alonso et al., 2015; García-Escarzaga et al., 2015 ). Shells from El Mazo come from the 2009 and 2010 excavation campaigns and they were found in squares V15 and V16 (Fig. 2). Shells from El Toral III come from the 2009 excavation and they were found in squares M4, M9, O6 and O8 (Fig. 2). All the shells were observed under the microscope and those with traces of clear anthropogenic modification were selected for study. Complete and fragmented shells from the same species than perforated shells, but with no signs of human manipulation, were also sorted out for analysis. In total, 104 shells from El Mazo and five from El Toral III were studied. Moreover, a perforated red deer canine from El Toral III was also included in the study.

\subsection{Methods}

3.2.1. Shells

3.2.1.1. Taxonomic identification. Taxonomic identification involved two steps; the characterization of the shell's general shape for class determination (e.g.

of whorls, shape of the aperture,

Table 2

Modern and archaeological reference collections used in the analysis.

lip, ventral and dorsal sides, and ornamentation to determine genus or species (Poppe and Gotot, 1993; Harasewych and Moretzsohn, 2010). The nomenclature employed here adopted classifications available in the CLEMAM seashell database (Check List of European Marine Mollusca Database. http://www.somali.asso.fr/clemam/ index.clemam.html, search performed on 15/08/2011).

3.2.1.2. Metric analysis. Differences between natural populations and archaeological samples bring to light the extent to which human choices were responsible for the accumulation. To this end, morphometric variables (shell length and width, width of the spire and aperture) recorded on the archaeological material were compared to those from reference collections for which the accumulator is known. The statistical analysis was performed using the Statistica 10.0 software.

3.2.1.3. Reference collections. Archaeological shells from El Mazo and El Toral III were compared to both archaeological and modern collections of the same species (Table 2). The modern reference collections were handcollected from different thanatocenoses along the Atlantic coast and, when possible, as close to the site as possible in order to compensate for the effect of latitude on shells size (Trussell, 2000). All shells visible to the naked eye were collected on the shore. A modern collection of Littorina obtusata comprises 328 hand-collected specimens from Brittany (Noirmoutier, France), in the Armorican Atlantic coast (Vanhaeren, 2002, 2010; Vanhaeren and d' Errico, 2003). Another modern collection of the same species comprises 200 hand-collected specimens from Santander (Cantabria, northern Spain), in the Cantabrian Atlantic coast (Alvarez Fernandez, 2006). Shells 
were collected from different rocky shores of the same areas in order to explore the size variability of the species when collected from close locations. The L. obtusata from El Toral III and El Mazo were also compared to 43 specimens from the Lower Magdalenian (level F) of Urtiaga Cave (Guipúzcoa, Basque Country, northern Spain, Utrilla, 1996), and 7 from the Upper Magdalenian (level E) of the same site (Utrilla, 1996).

A modern collection of Trivia sp. comprises 100 specimens from Lugo (Galicia, northern Spain), located in the Cantabrian Atlantic coast (Alvarez Fern andez, 2006). Trivia shells were also compared to 61 gastropods of the same species recovered from the burial II of Los Canes (Arangas, Asturias, northern Spain) and attributed to the Mesolithic (Alvarez Fern andez, 2006 ).

3.2.1.4. Microscopic analysis. Shell surfaces show microscopic modifications testifying to events occurring either during the life of the mollusk or post mortem. In the case of shells collected and/or modified by prehistoric groups, microscopic analyses provide information relevant to the environment in which shells were collected as well as subsequent taphonomic and anthropogenic modifications (d' Errico et al., 2005; Dupont, 2006; Taborin, 1998; Vanhaeren et al., 2013). A Leica Z6 APO microscope equipped with a digital camera was used to document surface modifications on each shell. The presence, location, and degree of natural modifications impeding microscopic analysis (calcite deposits, cracks) were recorded for each specimen, alongside the degree of preservation of the shell's original shape and ornamentation. Natural and anthropogenic modifications such as fractures, use-wear, modifications produced by suspension (e.g. perforations, residues, incisions) were also systematically recorded.

\subsubsection{Red deer canine}

The protocol is based on the recording of morphological variables discriminating for the age and sex identification of the deer on which the teeth were collected (d' Errico and Vanhaeren, 2002). These criteria were established by the authors, through the analysis of modern reference collections consisting of canines taken from red deer of known age and sex from the island of Rum (Benton et al., 1995; Clutton-Brock et al., 1982, 1997; Coulson et al., 1997; Kruuk et al., 1999; d' Errico and Vanhaeren, 2002). Four morphological variables were recorded on the canine. Variables includes five stages of occlusal wear, three stages of development of the root, the state of calcification of the pulp cavity, and the removal by wear of the disto-linguocervical-lobe (DLCL), a prominence located on the posterior edge of the lingual side of the crown (Greer and Yeager, 1967).

Usually, the protocol also includes the registration of metrical variables to complete the results of the morphological analysis (d' Errico and Vanhaeren, 2002; Rigaud et al., 2010; Rigaud, 2013). However, the state of preservation of the canine from El Toral III did not allow its measurement.

4. Results

4.1. Shell beads

\subsubsection{Shell identification}

In this study, 34 items considered personal ornaments were identified (30 shell beads at El Mazo, and three shell beads and one perforated red deer canine at El Toral III). At El Mazo, two different marine shells, Littorina obtusata (Linne, 1758) and Trivia sp., were used as personal ornaments. At El Toral III only shell beads made of Trivia sp. were found (Table 3). In northern Iberia two different species of Trivia sp. are present: Trivia monacha and Trivia arctica. These two species can be identified by the presence of dark spots exclusively on the dorsal side of the Trivia monacha. When shell ornamentation is not preserved, as in archaeological contexts, neither the morphology, nor the size, nor the ridges density of the shells allow the identification of the two species (Dommergues et al., 2006).

Absence of ornamentation on the archaeological specimens, due to taphomomic alterations, limits the identification of the Trivia sp. to the genus level in this study.

Table 3

Number of modified and unmodified shells within species identified in personal ornaments at El Mazo and El Toral III.

\begin{tabular}{|c|c|c|c|c|c|c|}
\hline Site & SU & Specie & $\begin{array}{l}\text { Broken } \\
\text { shells }\end{array}$ & $\begin{array}{l}\text { Intact } \\
\text { shells }\end{array}$ & $\begin{array}{l}\text { Broken } \\
\text { beads }\end{array}$ & Beads \\
\hline \multirow[t]{9}{*}{ El Mazo } & $100 / 101$ & L. obtusata & 11 & 6 & 4 & 9 \\
\hline & & Trivia sp. & . & . & . & 1 \\
\hline & 102 & L. obtusata & 1 & . & . & . \\
\hline & 103 & L. obtusata & 4 & 1 & . & 1 \\
\hline & & Trivia sp. & . & . & . & 1 \\
\hline & 105 & L. obtusata & 17 & 15 & 4 & 3 \\
\hline & & Trivia sp. & 2 & 1 & . & 1 \\
\hline & 106 & L. obtusata & 3 & 4 & . & . \\
\hline & 107 & L. obtusata & 4 & 5 & . & 6 \\
\hline \multirow[t]{4}{*}{ El Toral III } & 17 & Trivia sp. & . & . & . & 1 \\
\hline & 19 & Trivia sp. & . & . & . & 1 \\
\hline & 20 & Trivia sp. & 2 & . & . & \\
\hline & 6 & Trivia sp. & . & . & . & 1 \\
\hline
\end{tabular}

4.1.2. Preservation

A large amount of the L. obtusata $(48 \%)$ is fragmented and four Trivia sp. show breakages (Fig. 3). The L. obtusata shells present stigma resulting from the surf action that led to a change in the general shape of the shells, including smoothing of the surface and flattening of the apex. 


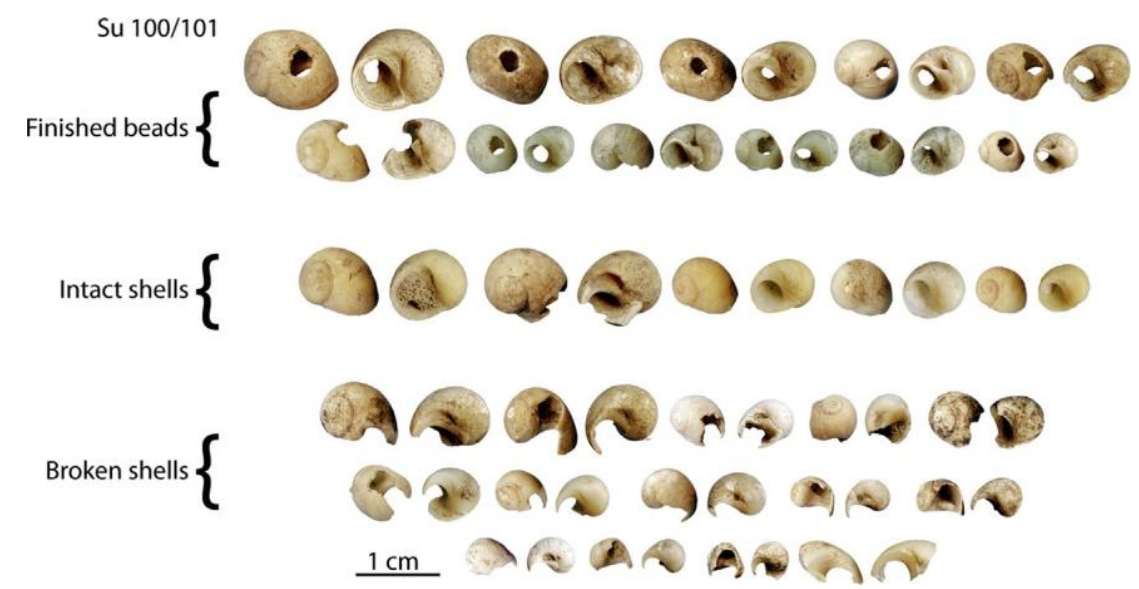

Fig. 3. Finished, intact and broken Littorina obtusata shells from stratigraphic unit 100/101 of El Mazo. 

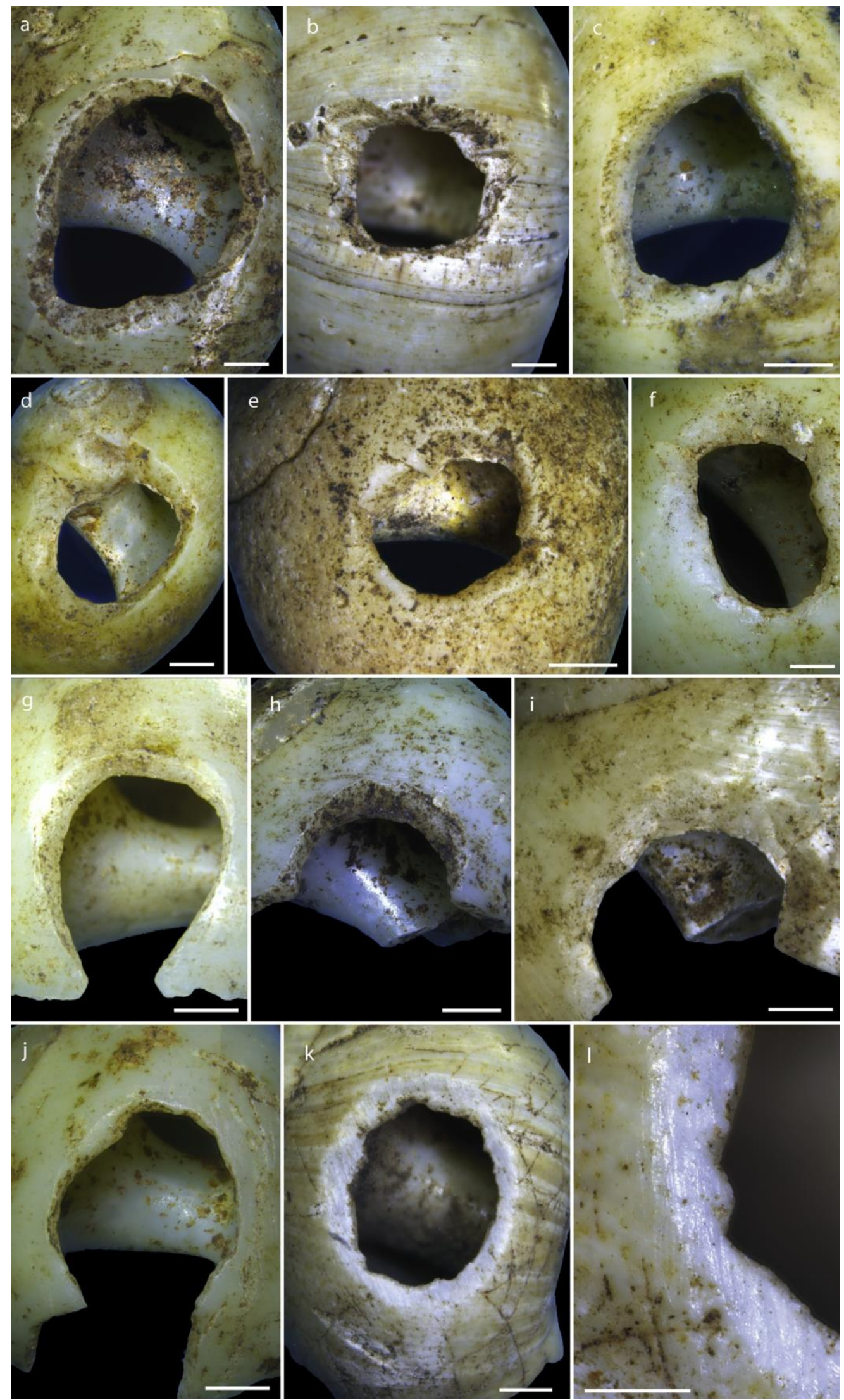

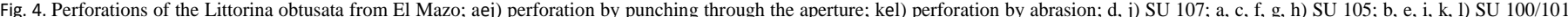
Scale $1 \mathrm{~mm}$. 


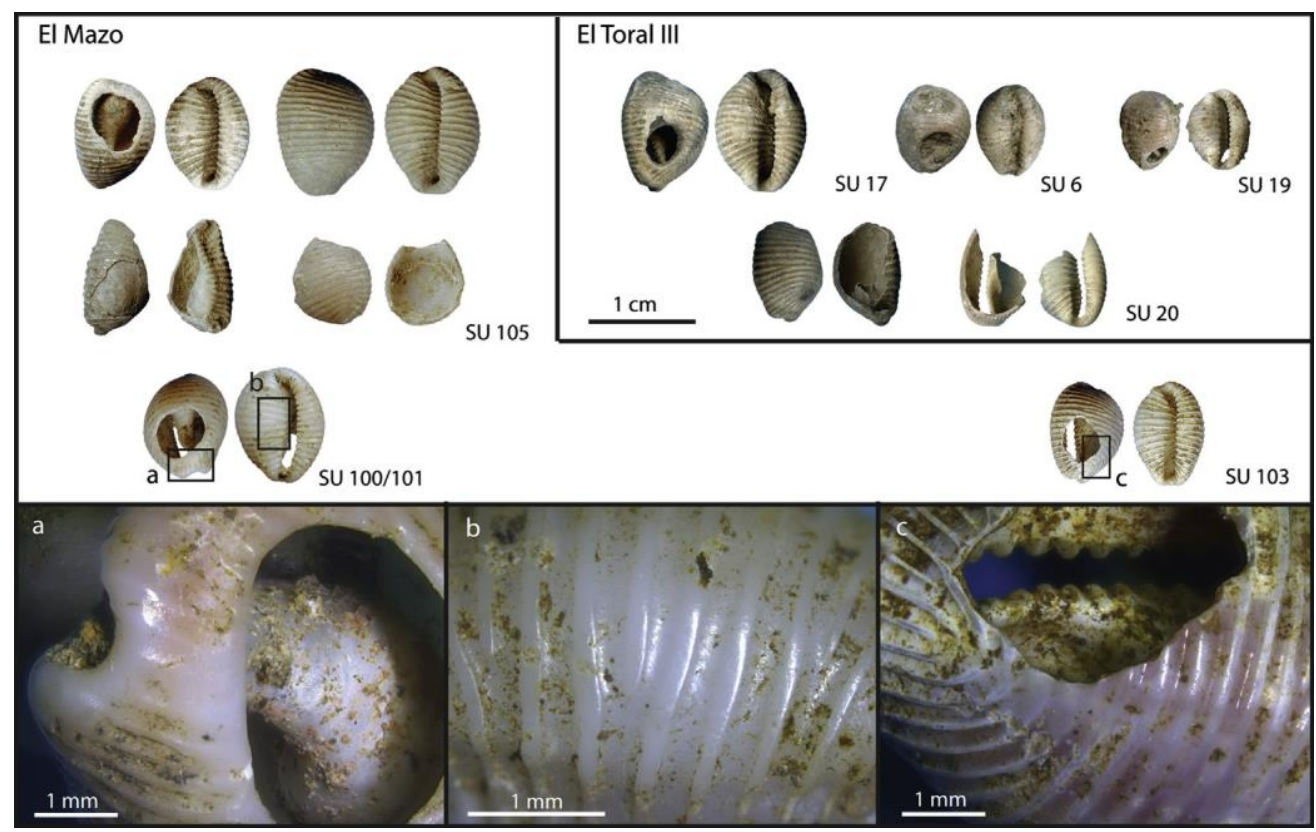

Fig. 5. Trivia sp. from El Mazo and El Toral III. Photos a, b and c show the location of the use wear observed on the shells.

\subsubsection{Technological analysis}

L. obtusata shells were perforated on the dorsal side of the last whorl. Perforations are regular in shape with oblique edges and all but one have microchippings on the outer shell wall (Fig. 4aej). Experimental data indicates that perforations, similar in size and shape to those on the archaeological specimens, are produced by punching through the aperture with a relatively soft material such as a bone point or a crab claw (d' Errico et al., 2005).
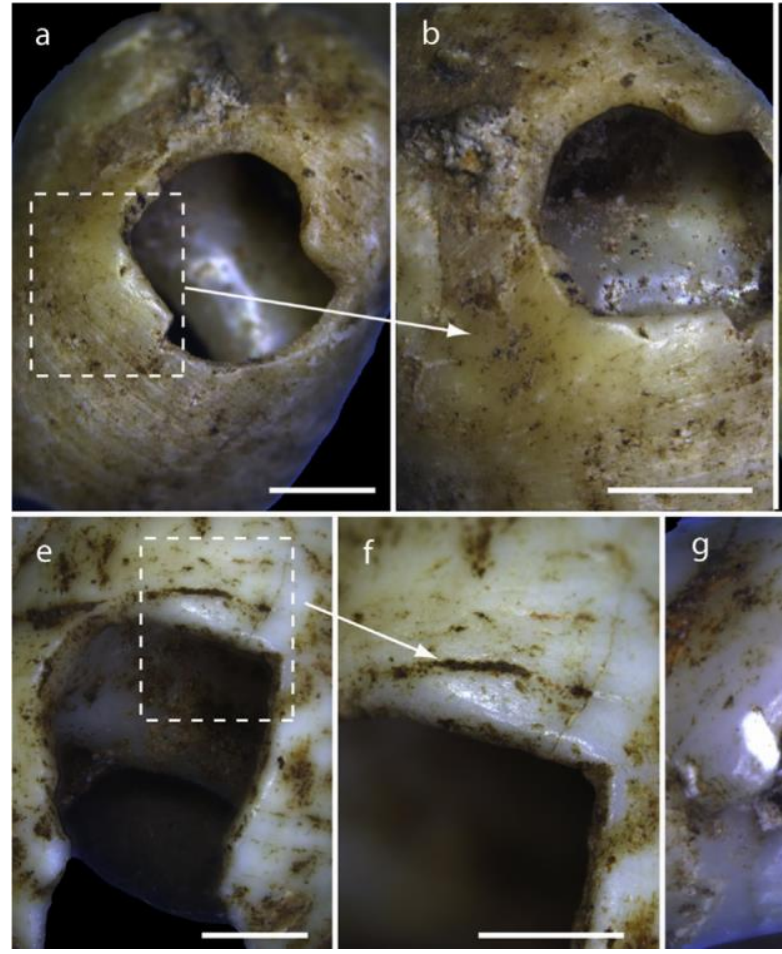

One perforated shell does not present these features. The perforation has flat cutting edge and parallel striations on the outer shell wall. The striations are obliquely oriented by comparison to the maximum length of the shell; extremities of the striations are thinner, elongated and present a sharp end (Fig. 4kel). Similar perforations have been experimentally obtained by abrading the shells across a slightly irregular rough grindstone (Harzhauser et al., 2007).

Fig. 6. Use wear registered on perforated shells from El Mazo shell midden; aed, geh) SU 100/101; e, f) 105. Scale $1 \mathrm{~mm}$. 


\begin{tabular}{|l|r|r|r|r|r|}
\hline Site & N & \multicolumn{2}{|c|}{ Mean } & \multicolumn{1}{l|}{ Min } & \multicolumn{2}{l|}{ Max } & \multicolumn{2}{l|}{ St dev } \\
\hline Urtiaga E & 7 & 13.78 & 8.49 & 15.97 & 2.94 \\
\hline Urtiaga F & 43 & 15.54 & 8.75 & 19.80 & 2.23 \\
\hline Bonhomme & 270 & 11.67 & 6.55 & 17.44 & 2.49 \\
\hline Souzeaux & 58 & 12.95 & 9.06 & 15.03 & 1.20 \\
\hline Noiremoutier & 31 & 12.43 & 4.86 & 14.79 & 1.94 \\
\hline La Concha & 100 &. & 5.00 & 12.50 &. \\
\hline La Maruca & 100 &. & 4.20 & 11.30 &. \\
\hline MazoPerf & 22 & 9.28 & 6.17 & 11.90 & 1.71 \\
\hline MazoNonperf & 36 & 8.79 & 6.67 & 11.39 & 1.42 \\
\hline
\end{tabular}

\begin{tabular}{|l|r|r|r|r|r|}
\hline Site & N & Mean & Min & Max & St dev \\
\hline Praileaitz & 122 & 4.48 & 2.49 & 7.51 & 1.14 \\
\hline Urtiaga E & 7 & 5.91 & 3.02 & 7.43 & 1.60 \\
\hline Urtiaga F & 43 & 7.23 & 4.36 & 9.08 & 1.13 \\
\hline Bonhomme & 270 & 6.14 & 3.07 & 9.82 & 1.38 \\
\hline Souzeaux & 58 & 7.17 & 4.68 & 8.11 & 0.74 \\
\hline Noiremoutier & 31 & 6.24 & 2.65 & 7.63 & 0.93 \\
\hline El Mazo perf. & 22 & 4.38 & 2.51 & 6.02 & 0.94 \\
\hline El Mazo intact & 36 & 4.11 & 2.69 & 5.80 & 0.86 \\
\hline
\end{tabular}
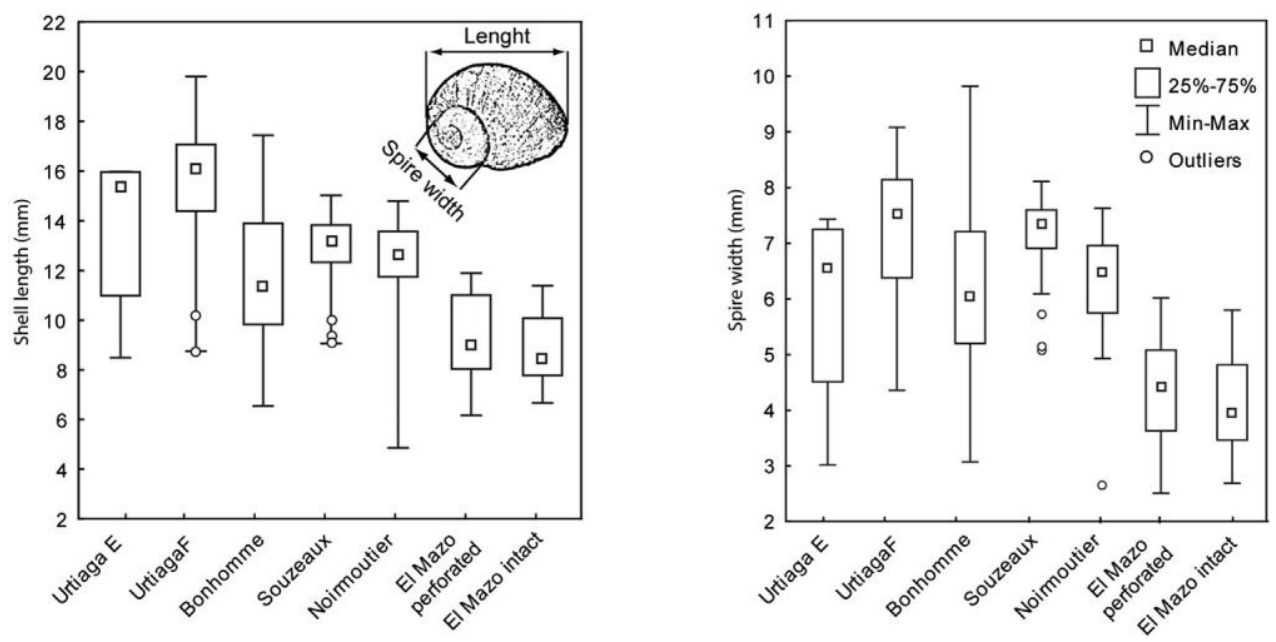

Fig. 7. Shell length and spire width recorded on perforated and intact L. obtusata from El Mazo, and measurements recorded from modern (Bonhomme, Souzeaux, Noirmoutier, La

Maruca and La Concha) and archaeological (Urtiaga E and F) reference collections. (Only length of the shells were available in Alvarez-Fern

andez $2006 \quad$ (p. 97) for the modern reference collections from La Maruca and La Concha.).

Comparison of the L. obtusata from El Mazo with those from reference collections indicates the former to be composed of significantly smaller shells than modern reference collections from Brittany and archaeological reference collections from northern Iberia (ManneWhitney U-test: $\mathrm{p}<0.05$, Tables 4

Trivia sp. shells were perforated on the dorsal side. The perforations are systematically located close to one of the two extremities of the dorsal side (Fig. 5). No preference for the upper or lower extremity is identified when looking at the shell from the aperture side, the swollen parietal region of the body whorl positioned on the left. A single piece, from El Toral III, has two perforations, each located at one extremity of the dorsal side of the shell (Fig. 5, SU6).

Perforations are regular in shape with edges perpendicular to the surface of the shell. Absence of micro-chippings on the outer shell wall and the difficulty to punch the shells from the inner, through the naturally very narrowed aperture, suggests that the shells were perforated by punching from the outside of the dorsal side.

\subsubsection{Use wear analysis}

Use wear, visible through the heavy smoothing all along the edge of the perforation, is identified on several L. obtusata (Fig. 6). Use of the shells has resulted in the fading of the micro-chipping due to the punching of the shell during the bead manufacture. Wear can take the form of a small flat and shiny surface, developed on the margin of the perforation either in the direction of the top of the shell (Fig. 6ceh) or of the aperture (Fig. 6a,b). Within the shells having use wear on their perforation, two are intact and four are broken. Broken shells have often partially lost their last whorl from the aperture and up to half of the perforation.

Two Trivia sp. from El Mazo present small use wear, smooth and highly shiny, located on the edge of the perforation, developed in direction of the extremity of the shells (Fig. 5aec). Use wear is also identified on the extremity of the aperture on one of the shells (Fig. 5a). The same shell also present use wear on the ventral side

(Fig. 5b).

4.1.5. Morphometric analysis and 5, Fig. 7). Length of the shells from El Mazo falls into the size range recorded on the shells from the Cantabrian modern reference collections. Median length and median width of the spires show that the unperforated shells tend to be smaller than the perforated shells (Tables 4 and 5, Fig. 7), but the result is statistically not significant (ManneWhitney U-test: $p>0.05$, Table 4).

Table 4

Results of the Mann Whitney U test performed on the shell length and spire width measured on archaeological specimens and reference collections.

$P$ value MareWhitney $U$ test

\begin{tabular}{lcc}
\hline Shell length & $<0.00001$ & Spire width \\
Bonhomme $\sim$ El Mazo intact & 0.000025 & $<0.00001$ \\
Bonhome $\sim$ El Mazo perforated & 0.000622 & $<0.00001$ \\
Urtiaga E $\sim$ El Mazo intact & 0.003669 & 0.007706 \\
Urtiaga E $\sim$ El Mazo perforated & $<0.00001$ & 0.019059 \\
Urtiaga F $\sim$ El Mazo intact & $<0.00001$ & $<0.00001$ \\
Urtiaga F $\sim$ El Mazo perforated & $<0.00001$ & $<0.00001$ \\
Noirmoutier $\sim$ El Mazo intact & $<0.00001$ & $<0.00001$ \\
Noirmoutier $\sim$ El Mazo perforated & $<0.00001$ & $<0.00001$ \\
Souzeaux $\sim$ El Mazo intact & $<0.00001$ & $<0.00001$ \\
Souzeaux $\sim$ El Mazo perforated & 0.211315 & $<0.00001$ \\
El Mazo peforated $\sim$ El Mazo intact & & 0.275842 \\
& &
\end{tabular}


Table 5

El Mazo shell raw measurements used in the Mann Whitney U test.

\begin{tabular}{|c|c|c|c|c|c|c|c|c|}
\hline Site & Year of excavation & Square & Stratigraphic unit & Species & Length & Spire width & Perf length & Perf width \\
\hline El Mazo & 2009 & V15 & 105 & L. obtusata & 11.22 & 5.72 & 3.71 & 2.89 \\
\hline El Mazo & 2009 & V 15 & 105 & L. obtusata & 10.03 & 5.54 & & \\
\hline El Mazo & 2009 & V 15 & 105 & L. obtusata & 9.49 & 4.37 & na & 3.05 \\
\hline El Mazo & 2009 & V 15 & 105 & L. obtusata & 10.09 & 5.08 & & 2.64 \\
\hline El Mazo & 2009 & V 15 & 105 & L. obtusata & 10.33 & 5.29 & & \\
\hline El Mazo & 2009 & V 15 & 105 & L. obtusata & 11.32 & 4.88 & & \\
\hline El Mazo & 2009 & V 15 & 105 & L. obtusata & 8.27 & 4.02 & & \\
\hline El Mazo & 2009 & V 16 & 105 & L. obtusata & 8.58 & 4.78 & 4.39 & 3.43 \\
\hline El Mazo & 2009 & V 16 & 105 & L. obtusata & 9.03 & 4.06 & 2.12 & 3.29 \\
\hline El Mazo & 2009 & V 16 & 105 & L. obtusata & 8.11 & 3.6 & & \\
\hline El Mazo & 2009 & V 16 & 105 & L. obtusata & 10.7 & 4.6 & & \\
\hline El Mazo & 2009 & V 16 & 105 & L. obtusata & 11.39 & 4.79 & & \\
\hline El Mazo & 2009 & V 16 & 105 & L. obtusata & 8.15 & 3.73 & & \\
\hline El Mazo & 2009 & V 16 & 105 & L. obtusata & 7.47 & 3.07 & & \\
\hline El Mazo & 2009 & V 16 & 105 & L. obtusata & 7.08 & 2.88 & & \\
\hline El Mazo & 2009 & V 16 & 105 & L. obtusata & 8.6 & 4.18 & & \\
\hline El Mazo & 2009 & V 16 & 105 & L. obtusata & 8.98 & 3.67 & & \\
\hline El Mazo & 2009 & V 16 & 105 & L. obtusata & 8.21 & 3.52 & & \\
\hline El Mazo & 2009 & V 16 & 105 & L. obtusata & 8.08 & 3.59 & & \\
\hline El Mazo & 2009 & V 16 & 105 & L. obtusata & 8.32 & 3.43 & & \\
\hline El Mazo & 2009 & V 16 & $100 / 101$ & L. obtusata & 11 & 4.98 & & \\
\hline El Mazo & 2009 & V 16 & $100 / 101$ & L. obtusata & 8.6 & 3.38 & & \\
\hline El Mazo & 2009 & V 16 & $100 / 101$ & L. obtusata & 6.8 & 2.69 & & \\
\hline El Mazo & 2009 & V 16 & $100 / 101$ & L. obtusata & 8.72 & 4.7 & & \\
\hline El Mazo & 2009 & V 16 & $100 / 101$ & L. obtusata & 11.02 & 4.5 & & \\
\hline El Mazo & 2009 & V 16 & $100 / 101$ & L. obtusata & 6.67 & 3.19 & & \\
\hline El Mazo & 2009 & V 16 & $100 / 101$ & L. obtusata & 7.33 & 3.22 & & \\
\hline El Mazo & 2009 & V 16 & $100 / 101$ & L. obtusata & 10.03 & 5.8 & & \\
\hline El Mazo & 2009 & V 16 & $100 / 101$ & L. obtusata & 7.34 & 3.23 & & \\
\hline El Mazo & 2009 & V 16 & $100 / 101$ & L. obtusata & 8.38 & 3.91 & & \\
\hline El Mazo & 2009 & V 16 & $100 / 101$ & L. obtusata & 11.01 & 4.75 & 3.03 & 2.77 \\
\hline El Mazo & 2009 & V 16 & $100 / 101$ & L. obtusata & 8.95 & 3.95 & 2.18 & 2.38 \\
\hline El Mazo & 2009 & V 16 & $100 / 101$ & L. obtusata & 11.47 & 5.71 & 3.28 & 3.6 \\
\hline El Mazo & 2009 & V 16 & $100 / 101$ & L. obtusata & 9.92 & 4.72 & 2.74 & 2.32 \\
\hline El Mazo & 2009 & V 16 & $100 / 101$ & L. obtusata & 9.07 & 4.62 & & 2.56 \\
\hline El Mazo & 2009 & V 16 & $100 / 101$ & L. obtusata & 6.17 & 2.51 & 2.43 & 2.03 \\
\hline El Mazo & 2009 & V 15 & 102 & L. obtusata & 8.2 & 4.32 & & \\
\hline El Mazo & 2009 & V 16 & 107 & L. obtusata & 8.03 & 3.74 & na & 2.99 \\
\hline El Mazo & 2009 & V 16 & 107 & L. obtusata & 10.09 & 4.47 & 4.25 & 3.7 \\
\hline El Mazo & 2009 & V 16 & 106 & L. obtusata & 10.14 & 5.33 & & \\
\hline El Mazo & 2009 & V 16 & 106 & L. obtusata & 10.81 & 5.53 & & \\
\hline El Mazo & 2009 & V 16 & 106 & L. obtusata & 7.04 & 2.94 & & \\
\hline El Mazo & 2009 & V 16 & 106 & L. obtusata & 8.57 & 4.13 & & \\
\hline El Mazo & 2009 & V 15 & $100 / 101$ & L. obtusata & 7.52 & 3.46 & 2.15 & 2 \\
\hline El Mazo & 2009 & V 15 & $100 / 101$ & L. obtusata & 8.67 & 4.84 & & \\
\hline El Mazo & 2009 & V 15 & $100 / 101$ & L. obtusata & 7.44 & 4.27 & 2.48 & 3.01 \\
\hline
\end{tabular}


Comparison of the Trivia sp. from El Mazo and El Toral III with those from reference collections shows that the four shells from El Mazo and one shell from El Toral III fall in the size range of the shells from Los Canes and the larger shells from the modern reference collection (Fig. 8). The two remaining shells from el Toral III have dimensions corresponding to the smallest shells of the modern reference collection.

\subsection{Red deer canine}

\subsubsection{Preservation}

The red deer canine from El Toral III (SU13A) is highly altered by chemical weathering (White and Hannus, 1983) visible through the presence of numerous pits on the surface of the crown attesting of dissolution process (Fig. 9).

\subsubsection{Attribution}

The morphology of the canine identifies the tooth as an upper left stag canine. Occlusal wear of the crown is highly developed and attributes the tooth to a red deer of an age comprised between 8 and 14 years. Considering that the pulpar cavity of the tooth is not visible, the apex of the root is fully calcified and the disto-linguo-cervical-lobe is still present, the age of the stag is closer to the lower limit of this age range, i.e. between 8 and 11 years.

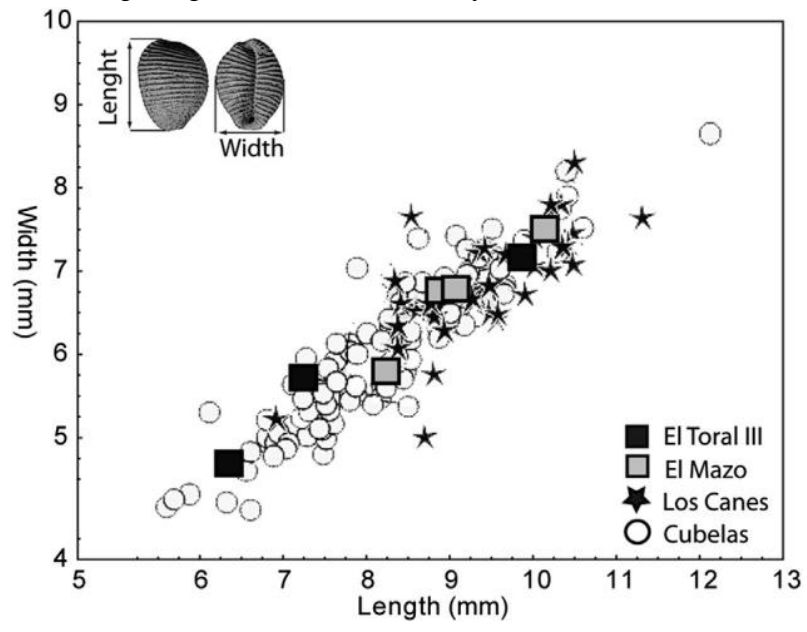

Fig. 8. Scattergram of length and width from Trivia sp. from El Mazo and El Toral III compared to measurements recorded from archaeological (Los Canes, burial II) and modern (Playa de Cubelas) reference collections (modified after Alvarez-Fern andez, 2006, p. 460).

\subsubsection{Technological analysis}

The perforation is located on the root of the canine, it is circular and is covered by regular circular striations on its straight edge (Fig. 9). Similar perforations have been experimentally produced, using the bifacial drilling technique with a pump or a bow drill (Gurova et al., 2013).

\subsubsection{Use wear analysis}
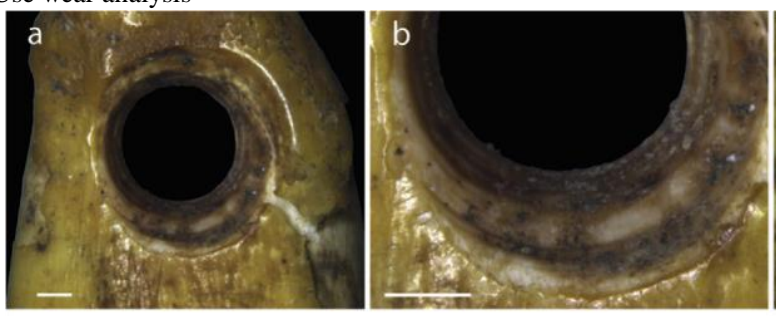

The margins of the perforation present an intense shine. The disto-lingual edge of the perforation is rounded and rotation marks are smoothed and less visible. Location of the use wear indicates the canine has been used and strung in a way to keep the tooth suspended by the disto-lingual edge (Fig. 9).

\section{Discussion}

\subsection{Acquisition}

Presence of alteration resulting from surf action on the surface of the $\mathrm{L}$. obtusata shells indicates that they were collected from one or more thanatocenoses (Taborin, 1993; Lozouet and Vigne, 1994). L. obtusata and Trivia sp. are intertidal taxa naturally present on the Atlantic shore. L. obtusata is abundant on the laminae of algae (Ascophyllum nodosum and Fucus vesiculosus) that cover temperate rocky shores and, although preferentially distributed in sheltered tidal areas, can occur in more or less brackish areas such as estuaries (Watson and Norton, 1987). Trivia sp. develops on sublittoral rocky shores up to $100 \mathrm{~m}$ deep, in areas rich in ascidians (Wayward and Ryland, 1996). Proximity of the sites with the seashore, characterized in the region by the presence of rocky tidal zones, suggests that the inhabitants of El Mazo likely have directly collected L. obtusata shells from local natural accumulations. Dead Trivia sp. are often washed up onto the beaches and could have also been collected by the human groups. Cantabrian tidal environment offered a large set of shells suitable for bead manufacture and this is documented in the personal ornaments used by other Mesolithic coastal societies (Rigaud, 2011). Exclusive use of two species for bead manufacture at the sites reflects targeted selection likely ruled by cultural norms.

Red deer was broadly present in Europe during the Holocene (Sommer et al., 2008). His consumption at Asturian sites is also frequently attested, including at El Toral III and El Mazo (AndreuAlarcon, 2013 ). Evidence of red deer hunting in several stratigraphic units identified at the site suggests that the group could have directly acquired the canine from one of their prey.

\subsection{Selection}

Morphometric analysis shows that L. obtusata from El Mazo are significantly smaller than those from northern modern reference collections from Brittany and examples abandoned at the nearby Upper and Lower Magdalenian site of Urtiaga.

Two factors, environmental conditions and human selection, may be responsible for size differences observed between the archaeological examples from El Mazo and the reference collections. Shell size tends to decrease with increased sea surface temperatures during the Pleistocene and the Holocene (Bailey and Craighead, 2003; Gutierrez-Zugasti, 2011 ). Difference in shell size could also result from water temperature differences and seasonal variations (Newkirk and Doyle,1975; Johannesson et al.,1993; Reid, 1993; Queiroga et al., 2011). The larger Magdalenian L. obtusata relative to El Mazo shells appear consistent with the climatic hypotheses. Latitudinal distance, linked to differences in water temperatures between modern reference collections from Brittany and those from El Mazo, could also explain the observed difference in size between the accumulations.
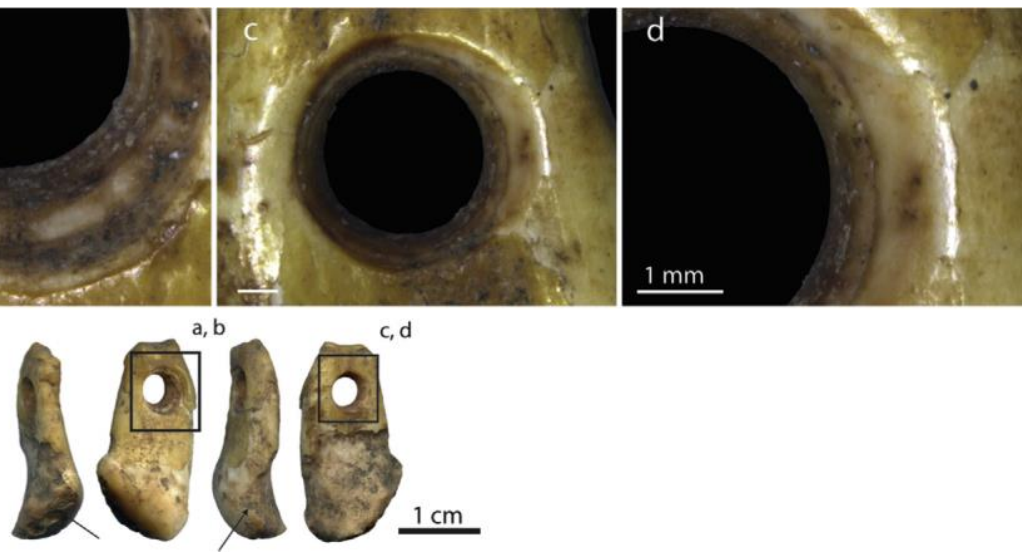

9. Perforation of the red deer canine from El Toral III (Area A, SU 13A). Lingual, distal, mesial and vestibular views of the canine. Arrows indicate surface alterations of the canine. 
Similar length range between modern reference collections from northern Iberia and El Mazo supports that the archaeological shells were randomly collected from a natural accumulation. In sum, there is no evidence that the

L. obtusata from El Mazo were sorted according to their size before being transported to the site.

Dimensions registered on the Trivia sp. from El Mazo and El Toral III mostly correspond to the size of the larger shells from the modern reference collection and to the size of the shells deposited in the burial II of Los Canes (Fig. 8). The latter accumulation is interpreted as the result of the selection of large shells suitable to be transformed into beads (Alvarez Fern andez, 2006). The small number of shells from El Mazo and El Toral III limits the discussion on possible anthropic selection according to their size.

The presence of a unique red deer canine also limits the discussion on selection of the teeth. As at El Toral III, the larger collection of red deer canines attributed to the Mesolithic in the region is composed of adult stags canines (Rigaud et al., 2010).

\subsection{Manufacture and use}

At El Mazo, technological analysis identifies intact and broken perforated and unperforated shells of the two species. Use wear are observed on the perforation of some, but not all, intact and broken shells. The presence of unmodified shells and perforated shells with no use wear suggests that shells were modified at the site. In situ bead manufacture is also sustained by the presence of unused perforated broken L. obtusata indicating that some shells were fractured during the bead manufacture process. Presence of use wear shows that some of the beads were worn before being discarded at the site. Broken and intact shell beads with use wear were probably accidentally lost at the site. Intact shell beads could also have been stored to be recycled in a new beadwork.

A unique unused $\mathrm{L}$. obtusata perforated by abrasion has been identified in the upper stratigraphic unit 100/101 from El Mazo, associated to several unused shells of the same species. L. obtusata perforated by punching are present all along the stratigraphy. In the upper stratigraphic unit, use wear take the form of a small flat and shiny surface developed on the margin of the perforation either in the direction of the top of the shell in some cases or of the aperture in other cases. The two different locations of the use wear suggest that the shells were attached according to two different systems of suspension. In the rest of the units, use wear is exclusively present in the form of smoother edges of the perforations.

A unique biperforated Trivia sp. was recorded in the SU 6 at El Toral III, while Trivia sp. are systematically monoperforated in the other units. The use of one or two perforations to suspend the Trivia sp. reflects at least two different systems of attachment that likely impacted the visual aspect given by the shells into the personal ornamentation they belonged.

Presence of use wear on the perforation of the red deer canine from El Toral III testifies of a long period of use of the canine before it was discarded at the site. Although a direct acquisition of the canine by the group is suggested, indirect acquisition through an exchange network cannot be excluded.

\subsection{Asturian personal ornaments in regional and European contexts}

Perforated L. obtusata and Trivia sp. were present all along the Atlantic coast during the Mesolithic (Dupont, 2006; Alvarez Fernandez, 2006; Rigaud, 2011). In northern Iberia, available technological data from La Garma A (layer Q, Alvarez Fern andez, 2006), Los Canes (layers 5, 6 and burial II, Alvarez-Fern andez, 2010) and El Truchiro (layer II, Alvarez-Fern andez et al., 2013 ) show that Trivia sp. were mostly monoperforated. Biperforated Trivia sp. were exclusively present in the layer 5 of Los Canes and layer Q of La Garma A (Alvarez Fern andez, 2006 ). By contrast, at Mesolithic sites from Muge Valley in Portugal (Alvarez Fern andez, 2008), Britain (Nolan, 1986; Mellars, 1987; Connock et al., 1992; Simpson, 1996; Hardy and Wickham-
Jones, 2009) and Brittany (Dupont, 2007), Trivia sp. were almost exclusively biperforated.

Presence of monoperforated Trivia sp. at El Mazo, and mono-and biperforated Trivia sp. at El Toral III perfectly fits with the regional personal ornaments diversity previously described (Alvarez Fernandez, 2006 ). Association of mono-and biperforated Trivia shells sharply differentiates Cantabrian ornaments from other areas of the Mesolithic Atlantic Europe.

Percussion and punching techniques for perforating the shells are commonly identified on Mesolithic personal ornaments in Europe (Dupont, 2006; Alvarez Fernandez, 2006; Perles and Vanhaeren, 2010; Rigaud, 2011; Cristiani et al., 2014). Percussion and abrasion techniques to perforate gastropods have been described for Mesolithic perforated Trivia sp. and Nassarius reticulatus in Cantabrian Spain (Alvarez Fern andez, 2006 ). The two different techniques used for perforating the shells in the layer 100/ 101 of El Mazo also correspond to the technical variability already identified in the area.

Perforated red deer canines are widely used in European Mesolithic societies (Rigaud et al., 2010). In northern Iberia, perforated canines have been recovered from two Mesolithic burials sites, Los Canes (Arias and Garralda, 1995) and La Brana (Vidal et al., 2008). Perforation technique identified on the canine from El Toral III differs from that of La Brana, where the 24 perfo- rated canines were perforated by scraping the both sides of the root with a lithic point, followed by a bifacial manual rotation with a lithic point (Rigaud et al., 2010). To the opposite, bifacial perforation by rotation using a pump or bow drill is attested in Bavaria at the Final Mesolithic burial site of Grobe Ofnet (Rigaud, 2013).

\subsection{Organization of the Asturian crafters}

Evidence of direct acquisition of the shells by members of the groups who occupied El Mazo and El Toral III, the presence of perforated and unperforated shells of the two species, the occurrence of use wear on some of the shell beads and evidence of accidental breakage of the shells during manufacture, suggest that shells were modified at the sites. Identification of all the technical stages for shell beads manufacture at the two shell middens indicates that the site were devoted not only to economic activities related to mollusk consumption (Gutierrez-Zugasti et al., 2014; Noval Fonseca, 2014), but also to symbolic productions. However, gastropods dedicated to be transformed into beads represent a minor part of the shells accumulated in the different layers (BelloAlonso et al., 2015; García-Escarzaga et al., 2015). Bead manufacture was probably a complementary activity incorporated (sensu Binford, 1978) into the economic activities of the group. Presence of shells collected alive in the tidal area, for consumption at the two sites and shells coming from thanatocenoses dedicated to bead manufacture show a sharp separation between the two systems of acquisition. Absence of recycling of shells used in diet, for material symbolic productions, seems to be a common behavior adopted by different Mesolithic societies along the Atlantic coast (Dupont, 2006, 2007). To the opposite, shells used for food are generally also used as tools in subsistence activities (CuencaSolana, 2014).

Diversity of the activities related to marine resource exploitation led at the sites, for subsistence and more slightly for symbolic activities, suggests a complex craft composition of the group. Evidence of shell bead manufacture is exclusively identified at El Mazo and El Toral III. Further investigations on shell assemblages recovered from excavations using similar field methods would allow a deeper discussion about such craft activities, their possible occurrence at other Asturian sites, or the existence of specific sites devoted to symbolic productions during this period.

Perforated Trivia sp. and L. obtusata are present at Mesolithic sites located afar from the shore [(Los Canes, (Asturias), El Espertín (Castile and Leon), ( Fano Martınez, 2004)]. Large distribution of these raw materials, outside their collection area, indicates that a complex scheduling and spatial organization ruled shell bead production and circulation during the Mesolithic. The existence of shell beads made of Trivia sp. and L. obtusata at the inland burial site of Los Canes indicates that the same common bead types were used by groups that relied on different subsistence (Arias, 2005e2006). The development of sharply 
separated economies on the one hand and the adoption of common personal ornamentation on the other hand, was likely ruled by different cultural mechanisms. Even if the last Asturian foraging societies were economically bounded, they were linked by common symbolic norms and likely belonged to the same exchange network.

\section{Conclusions}

Personal ornaments analysis from El Mazo and El Toral III shell middens allows the characterization of the craft organization and cultural network developed by the Asturian Mesolithic societies. By investigating raw material procurement, selection strategies and manufacture processes, this paper shows that the Asturian shell bead production was disconnected from the marine resource exploitation for both economic and technical purposes. All the technical steps required for bead production were conducted at the sites, from collection of the shells, to bead manufacture and use. In contrast, a task specific location, dedicated to raw material sorting for bead production, has been identified at an Epipalaeolithic site located along the northern Iberian Atlantic coast (Rigaud et al., 2014). Absence of this type of site in the Asturian context suggests that bead production was highly variable and in constant change in North Atlantic Spain between the end of the Pleistocene and the beginning of the Holocene. Absence of segmentation in the stages of shell beads manufacture at the beginning of the Holocene, likely reflects a shift in social organization with respect to previous times.

Finally, some scholars have proposed the existence of territoriality at least at the end of the Asturian Mesolithic, with the existence of both coastal and inland foraging societies developing distinct economies (Arias, 2005e2006) and also different funerary rites (Arias and Alvarez-Fern andez, 2004; Arias Cabal, 2007, Gutierrez- Zugasti et al., 2011). Presence of common associations of bead types within these societies depicts the interaction networks that may have existed during the Mesolithic in northern Iberia.

\section{Acknowledgements}

This research was conducted during a post-doctoral research consecutively granted by the Fyssen Foundation and the Marie Curie COFUND Action to SR. This research was part of the project HAR2013-46802-P, and IGZ was supported by the Juan de la Cierva programme (JCI-2012-12094), both funded by the Spanish Ministry of Economy and Competitiveness. Four and two radiocarbon dates from El Toral III were funded by the UTE Pendueles-Llanes and the Government of the Principado de Asturias, respectively. The authors would like to thank David Cuenca-Solana, Manuel Gonzalez- Morales, María NovalFonseca, Lucía Agudo-Perez and the UTE Pendueles-Llanes for their help in different stages of this research.

\section{References}

Alvarez Fernandez, E., 2006. Los objetos de adorno-colgantes del Paleolitico superior y del Mesolitico en la Cornisa Cantabrica y en el Valle del Ebro: una vision europea. Universidad de Salamanca, Salamanca.

Alvarez Fer nandez, E., 2008. Los colgantes de los grupos cazadores recolectores en Europa: las materias primas y sus fuentes de aprovisionamiento. In: Acercandonos Al Pasado. Prehistoria En 4 Actos. Museo Arqueologico Nacional, Madrid, pp. 1e17.

Alvarez-Fer nandez, E., 2010. Limpets \& Periwinkles in Cantabrian Spain between 22,000 and 15,000 Cal BC: Archaeomalacological Remains at Altamira Cave. In: Revista Facultat ii de Istorie a Universitat, ii Cres, tine Dimitrie Cantemir, Serie Istorie1. Ser. Noua 1, pp. $32 \mathrm{e} 51$.

Alvarez-Fer nandez, E., Aparicio Alonso, M.T., Armendariz Gutierrez, A., Ontan on Peredo, R., Arias Cabal, P., 2013. Etude archeomalacologique du gisement mesolithique de El Truchiro (Omon o, Ribamontan al Monte, Cantabrie). Anthropozoologica 48, 153e170.

Ambrose, W.R., 1967. Archaeology and Shell Middens. Archaeology and Physical Anthropology in Oceania 2, 169e187.

Andersen, S.H., 2000. "Køkkenmøddinger" (Shell Middens) in Denmark: a survey. Proceedings of the Prehistoric Society 66, 361e384. http://dx.doi.org/10.1017/ S0079497X00001857.

Andreu-Alarcon, S., 2013. La gestion de los recursos faunísticos en el Mesolítico del oriente de Asturias: el estudio arqueozoologico de los yacimientos de El Mazo y El Toral (Master thesis). Universidad de Cantabria, Santander.
Arias Cabal, P., 2007. Neighbours but diverse: social change in north-west Iberia during the transition from the Mesolithic to the Neolithic (5500e4000 cal BC). In: Whittle, A. Cummings, V. (Eds.), Going over: the Mesolithic-Neolithic Transition in North-west Europe, vol. 297. Oxford University Press, Oxford, pp. 53e71.

Arias, P., 2005. Determinaciones de isotopos estables en restos humanos de la region cantabrica. Aportacion al estudio de la dieta de las poblaciones del Mesolítico y el Neolítico. Munibe Antropologia y Arqueologia 57, 359e374.

Arias, P., Alvarez-Fernandez, E., 2004. Iberian Foragers and funerary ritual. A review of Paleolithic and Mesolithic evidence on the Peninsula. In: Gonzalez Morales, R., Clark, G.A. (Eds.), The Mesolithic of the Atlantic Façade: Proceedings of the Santander Symposium, Anthropological Research Papers No 55. Arizona State University, Tempe, pp. $225 \mathrm{e} 248$.

Arias, P., Cubas, M., Fano, M.A .N., Jorda Pardo, J.F., Salzmann, C., Teichner, F., Teira, L.C., 2015. Where are the "Asturian" dwellings? An integrated survey programme on the Mesolithic of northern Spain. Antiquity 89, 783 e799.

Arias, P., Garralda, M.D., 1995. Les sepultures Epipaleolithiques de la Cueva de Los Canes (Asturies, Espagne). In: Otte, M. (Ed.), Nature et Culture. ERAUL, Liege, pp. 869e895.

Bailey, G.N., Craighead, A.S., 2003. Late Pleistocene and Holocene coastal palaeoeconomies: a reconsideration of the molluscan evidence from northern Spain. Geoarchaeology 18 $175 \mathrm{e} 204$.

Balbo, A., Madella, M., Godino, I.B., Alvarez, M., 2011. Shell Midden research: an interdisciplinary agenda for the Quaternary and Social Sciences. Quaternary International $239,147 \mathrm{e} 152$.

Bartosiewicz, L., Zapata, L., Bonsall, C., 2010. A tale of two Shell Middens: the natural versus the cultural in "Obanian" deposits at Carding Mill Bay, Oban, Western Scotland. In VanDerwarker, A.M., Peres, T.M. (Eds.), Integrating Zooarchaeology and Paleoethnobotany. Springer, New York, pp. 205e225.

Bello-Alonso, P.. Ozkorta-Escribano, L., Gutierrez-Zugasti, I., 2015. Un acercamiento a aprovechamiento de los recursos litorales durante el Mesolítico: los invertebrados marinos del abrigo de El Toral III (Llanes, Asturias). In: Gutierrez Zugasti, I., Cuenca Solana, D., Gonzalez Morales, M.R. (Eds.), La Arqueomalacología en la Península Iberica: Nuevas Aportaciones. Nadir Ediciones, Santander, pp. 91e99.

Benton, T.G., Grant, A., Clutton-Brock, T.H., 1995. Does environmental stochasticity matter? Analysis of red deer life-histories on Rhum. Evolutionary Ecology 9, 559e574.

Biagi, P., 2013. The shell middens of Las Bela coast and the Indus delta (Arabian Sea, Pakistan). Arabian Archaeology and Epigraphy 24, 9e14.

Bicho, N., Haws, J., 2008. At the land's end: Marine resources and the importance of fluctuations in the coastline in the prehistoric hunteregatherer economy of Portugal. Quaternary Science Reviews 27, 2166e2175.

Binford, L.R., 1968. New perspectives. In: Archeology. Aldine, Chicago.

Binford, L.R., 1978. Nunamiut Ethnoarchaeology (Studies in Archeology). Academic Press, New York, NY.

Clark, G.A., 1983. The Asturian of Cantabria. Early Holocene Hunter-Gatherers in Northern Spain. Arizona State University Press, Tucson.

Clark, G.A., 2004. The Iberian Mesolithic in the European Context. In: Gonzalez Morales, M.R., Clark, G.A. (Eds.), The Mesolithic of the Atlantic Façade: Proceedings of the Santander Symposium, Anthropological Research Papers 55. Arizona State University, pp. $205 \mathrm{e} 223$

Clune, G., Harrison, R., 2009. Coastal Shell Middens of the Abydos Coastal Plain, Western Australia. Archaeology in Oceania 44, 70e80.

Clutton-Brock, T.H., Guinness, F.E., Albon, S.D., 1982. Red Deer. Behavior and Ecology of Two Sexes. The University of Chicago Press, Chicago.

Clutton-Brock, T.H., Rose, K.E., Guinness, F.E., 1997. Density-related changes in sexual selection in red deer. Proceedings, Royal Society of London 264, 1509e1516.

Colonese, A.C., Mannino, M.A., Bar-Yosef Mayer, D.E., Fa, D.A., Finlayson, J.C., Lubell, D. Stiner, M.C., 2011. Marine mollusc exploitation in Mediterranean prehistory: an overview. Quaternary International 239, 86e103.

Connock, K.D., Finlayson, B., Millis, C.M., 1992. Excavation of a Shell Midden Site at Carding Mill Bay, near Oban, Scotland. Glasgow Archaeological Journal 17, 25 e38.

Coulson, T., Albon, S.D., Guinness, F.E., Pemberton, J., Clutton-Brock, T.H., 1997. Population substructure, local density and calf winter survival in red deer (Cervus elaphus). Ecology $78,852 \mathrm{e} 863$.

Cristiani, E., Farbstein, R., Miracle, P., 2014. Ornamental traditions in the Eastern Adriatic: the Upper Palaeolithic and Mesolithic personal adornments from Vela Spila (Croatia). Journal of Anthropology and Archaeology 36, 21 e31.

Cuenca-Solana, D., 2014. The use of shells by Hunter-Fisher-Gatherers and Farmers from the Early Upper Palaeolithic to the Neolithic in the European Atlantic Façade: a technological Perspective. Journal of Island and Coastal Archaeology 1e24. http://dx.doi.org/10.1080/15564894.2014.934491.

Cunha, E., Umbelino, C., Cardoso, F., 2002. New anthropological data on the mesolithic communities from Portugal: the shell, middens from Sado. Human Evolution 17, 187e197.

d’ Errico, F., Henshilwood, C., Vanhaeren, M., Van Niekerk, K., 2005. Nassarius kraussianus shell beads from Blombos Cave: evidence for symbolic behaviour in the Middle Stone Age. Journal of Human Evolution 48, 3e24.

d'Errico, F., Vanhaeren, M., 2002. Criteria for identifying red deer (Cervus elaphus) age and sex from their canines. Application to the study of Upper Palaeolithic and Mesolithic Ornaments. Journal of Archaeological Science 29, 211e239.

Dommergues, E., Dommergues, J.L., Dommergues, C.H., 2006. Deux especes sous un $\mathrm{e}^{\wedge} \mathrm{me}$ masque. Le point de vue paleontologique piege par les coquilles de deux especes europeennes de Trivia (Mollusca, Gastropoda). Revue Paleobiologie 25, 775e790. 
Dupont, C., 2006. La malacofaune de sites mesolithiques et neolithiques de la façade atlantique de la France: Contribution a l'economie et a l'identite culturelle des groupes concernes. British Archaeological Reports. Archeopress, International Series 1571, Oxford.

Dupont, C., 2007. Les amas coquilliers mesolithiques de Teviec et d'Hoedic et le depo^t coquillier neolithique d'er Yoc'h: de la ressource alimentaire a l'utilisation des coquilles vides. Melvan Revue Deux ^^les 4, 251e264.

Erlandson, J., 2001. The archaeology of aquatic adaptations: paradigms for a new millennium. Journal of Archaeological Research 9, 287e350.

Fano, M.A., Gutierrez-Zugasti, I., Alvarez Fernandez, E., Fernandez-García, R., 2013. The exploitation of the Bay of Biscay (North of Spain) by Late Glacial and Postglacial societies. In: Bailey, G., Hardy, K. (Eds.), Shell Energy: Prehistoric Coastal Resources Strategies. Oxbow book, Oxford, pp. 155e166.

Fano Martınez, M.A., 2004. Un nuevo tiempo: el Mesolítico en la region Cantabrica. Kobie 8, $337 \mathrm{e} 402$.

García-Escarzaga, A., Gutierrez-Zugasti, I., Gonzalez-Morales, M.R., 2015. Analisis arqueomalacologico de la unidad estratigrafica 108 del conchero mesolítico de El Mazo (Llanes, Asturias): conclusiones socio-economicas y metodologicas. In: Gutierrez-Zugasti, I., Cuenca-Solana, D., Gonzalez-Morales, M.R. (Eds.), La Investigacion Arqueomalacologica en la Península Iberica: Nuevas Aportaciones. Nadir Ediciones, Santander, pp. 77 e89.

Gonzales-Morales, M.R., 1982. El Asturiense y otras culturas locales. La explotacion de las areas litorales de la region cantabrica en los tiempos epipaleolíticos. Centro de Investigacion y Museo de Altamira, Santander.

Gonzales-Morales, M.R., Marquez Uría, M.C., Díez Gonzales, T.E., Ortea, J.A., Volman, K.C., 1980. El conchero asturiense de la Cueva de Mazaculos II (La Franca, Asturias): Campanas de 1976 a 1978. In: Not. Arqueologico His $\sim$ panico 9. Ministerio de Cultura, Madrid.

Greer, K.R., Yeager, H.W., 1967. Sex and age indications from upper canine teeth of Elk (Wapiti). Journal of Wildlife Management 31, 408e417.

Gurova, M., Bonsall, C., Bradley, B., Anastassova, E., 2013. Approaching prehistoric skills: experimental drilling in the context of bead manufacturing. Bulgarian EJournal of Archaeology 3, 201e221.

Gutierrez-Zugasti, I., 2009. An examination of Mesolithic shellfishing activities in the lower Ason river basin (Cantabria, Spain). In: McCartan, S., Schulting, R.J., Warren, G., Woodman, P. (Eds.), Mesolithic Horizons. Proceedings of the VII International Conference on the Mesolithic in Europe. Oxbow Books, Belfast, pp. 161e166.

Gutierrez-Zugasti, I., 2011. Coastal resource intensification across the PleistoceneHolocene transition in Northern Spain: evidence from shell size and age distributions of marine gastropods. Quaternary International 244, 54e66.

Gutierrez-Zugasti, I., Andersen, S.H., Araújo, A.C., Dupont, C., Milner, N., MongeSoares, A.M., 2011. Shell midden research in Atlantic Europe: state of the art, research problems and perspectives for the future. Quaternary International 239, $70 \mathrm{e} 85$.

Gutierrez-Zugasti, I., Cuenca-Solana, D., Gonzales-Morales, M.R., García-Moreno, A., 2013a. Exploitation of molluscs as food during the Gravettian at Fuente del Salín cave (Cantabria, Northern Spain). In: Daire, M.Y., Dupont, C., Baudry, A., Billard, C., Large, J.M., Lespez, J.M., Normand, E., Scarre, C. (Eds.), Anciens Peuplements Littoraux et Relations Homme/Milieu Sur Les $\mathrm{Co}^{\wedge}$ tes de l'Europe Atlantique/Ancient Maritime Communities and the Relationship between People and Environment along the European Atlantic Coasts. British Archaeological Reports International Series, Oxford, pp. 491e500.

Gutierrez-Zugasti, I., Gonzalez-Morales, M.R., 2014. Intervencion arqueologica en 1 a cueva de El Mazo (Llanes, Asturias): campan as de 2009, 2010 y 2012. Excavaciones Arqueologicas en Asturias 2007e2012. Consejería de Cultura y Deporte del Gobierno del Principado de Asturias, Oviedo, pp. 159e167.

Gutierrez-Zugasti, I., Gonzales-Morales, M.R., Cuenca-Solana, D., Fuertes, N., GarcíaMoreno, A., Ortiz-Menendez, J.E., Rissetto, J., Torres, T.D., 2013b. Back to the Asturian: first results from the Mesolithic shell midden site of El Mazo (Asturias, Northern Spain). In: Daire, M.Y., Dupont, C., Baudry, A., Billard, C., Large, J.M., Lespez, L., Normand, E., Scarre, C. (Eds.), Anciens Peuplements Littoraux et Relations Homme/Milieu Sur Les $\mathrm{Co}^{\wedge}$ tes de l'Europe Atlantique/Ancient Maritime Communities and the Relationship between People and Environment along the European Atlantic Coasts, 2570. British Archaeological Reports International Series, Oxford, pp. 483e490.

Gutierrez-Zugasti, I., Gonzales Morales, M.R., Cuenca Solana, D., Fuertes, N., García Moreno, A., Ortiz-Menendez, J.E., Rissetto, J., Torres, T.D., 2014. La ocupacion de la costa durante el Mesolítico en el Oriente de Asturias: primeros resultados de las excavaciones en la cueva de El Mazo (Andrín, Llanes). Archaeofauna 23, 25e38.

Harasewych, J., Moretzsohn, F., 2010. The Book of Shells: a Life-size Guide to Identifying and Classifying Six Hundred Seashells. University of Chicago Press.

Hardy, K., Wickham-Jones, C., 2009. Mesolithic and Later Sites Around the Inner Sound, Scotland: the Work of the Scotland's First Settlers Project 1998e2004 (Scottish Archaeological Internet Reports [online] No. 31). Society of Antiquaries of Scotland, Edinburgh.

Harzhauser, M., Lenneis, E., Neugebauer-Maresh, C., 2007. Freshwater gastropods as Neolithic adnornment: size selectiveness and perforation morphology as a result of grinding techniques. Annals Naturhistorie Museum Wien 108 A, 1e13.

Johannesson, K., Johannesson, B., Rolan-Aalvarez, E., 1993. Morphological differentiation and genetic cohesiveness over a microenvironmental gradient in the marine snail Littorina saxatilis. Evolution 47, 1770e1787.

Komso, D., Vukosavljevic, N., 2011. Connecting coast and inland: perforated marine and freshwater snail shells in the Croatian Mesolithic. Quaternary International 244, 117e125.

Kruuk, L.E.B., Clutton-Brock, T.H., Albon, S.D., Pemberton, J.M., Guinness, F.E., 1999. Population density affects sex ratio variation in red deer. Nature 399, 459e461.
Lozouet, P., Vigne, J.-D., 1994. Les invertebres. In: Vigne, J.-D. (Ed.), L'île de Lavezzi, Hommes, Animaux, Archeologie et Marginalite (XIII, XX S., Bonifacio, Corse). Editions CNRS, Paris, pp. $155 \mathrm{e} 164$

Madariaga de la Campa, B., Fernandez Pato, C.A., 1985. Estudio malacologico de la Cueva de "El Juyo,". In: Barandiaran, I., Freeman, L.G., Gonzales Echegaray, J., Klein, R.G. (Eds.), Excavaciones en la Cueva del Juyo. Centro de Investigacion y Museo de Altamira, Santander, pp. $77 \mathrm{e} 95$.

Marean, C.W., 2014. The origins and significance of coastal resource use in Africa and Western Eurasia. Journal of Human Evolution 77, 17e40.

Marín-Arroyo, A.B., 2013. Human response to Holocene warming on the Cantabrian Coast (northern Spain): an unexpected outcome. Quaternary Science Reviews 81, 1e11.

Meehan, B., 1983. A matter of choice? Some thoughts on shell-gathering strategies in Northern Australia. In: Grigson, C., Clutton-Brock, J. (Eds.), Animals and Archaeology: Shell Middens, Fishes and Birds, British Archaeological Reports International Series, pp. 3e17.

Mellars, P., 1987. Excavations on oronsay: prehistoric human ecology on a small island. Edinburgh University Press, Edinburgh.

Newkirk, G., Doyle, R., 1975. Genetic analysis of shell shape variation in Littorina saxatilis on an environmental cline. Marine Biology 30, 227 e237.

Nolan, W., 1986. Cnoc Coig: the Spatial Analysis of a Late Mesolithic Shell Midden in Wester Scotland (Ph.D. thesis). University of Sheffielld, Sheffield.

Noval Fonseca, M., 2014. Excavacion arqueologica en la cueva de El Toral III (Andrín, Llanes). In: Excavaciones Arqueologicas en Asturias 2007e2012. Cons. Cult. Deporte Gob. Principado Astur, Oviedo, pp. 381e384.

Ortea, J.A., 1986. The malacology of La Riera cave. In: Straus, L.G., Clark, G.A. (Eds.), La Riera Cave. Stone Age Hunter-Gatherer Adaptations in Northern Spain. Arizona State University, Tempe, pp. $289 \mathrm{e} 313$.

Perles, C., Vanhaeren, M., 2010. Black Cyclope neritea Marine shell ornaments in the Upper Palaeolithic and Mesolithic of Franchthi Cave, Greece: arguments for intentional Heat Treatment. Journal of Field Archaeology 35, 298e309.

Poppe, G.T., Gotot, Y., 1993. European Seashells. (Scaphopoda, Bivalvia, Cephalopoda). Hemmen, Wiesbaden.

Queiroga, H., Costa, R., Leonardo, N., Soares, D., Cleary, D.F.R., 2011. Morphometric variation in two intertidal littorinid gastropods. Contributions to Zoology 80, $201 \mathrm{e} 211$.

Reid, D., 1993. Barnacle-dwelling ecotypes of three British Littorina species and the status of Littorina neglecta Bean. Journal of Molluscan Studies 59, 51e62.

Reimer, P., Bard, E., Bayliss, A., Beck, J.W., Bronk Ramsey, C., Blackwell, P.G., Cheng, H., Edwards, R.L., Friedrich, M., Grootes, P.M., Guilderson, T.P., Haflidason, H., Hajdas, I., Hatte, C., Heaton, T.J., Hoffmann, D.L., Hogg, A.G., Hughen, K.A., Kaiser, K.F., Kromer, B., Manning, S.W., Niu, M., Reimer, R.W., Richards, D.A., Scott, E.M., Southon, J.R., Staff, R.A., Turney, C.S.M., van der Pflicht, J., 2013. IntCal13 and Marine13 radiocarbon age calibration curves 0e50,000 years cal BP. Radiocarbon 55, 1869e1887.

Rick, T.C., Reeder-Myers, L.A., Cox, C.J., Sperling, S.T., Jansen, A., Hines, A.H., 2014. Shell Middens, cultural chronologies, and coastal settlement on the Rhode River Sub-Estuary of Chesapeake Bay, Maryland, USA. Geoarchaeology 29, 371e388.

Rigaud, S., 2011. La parure: traceur de la geographie culturelle et des dynamiques de peuplement au passage Mesolithique-Neolithique en Europe ( $\mathrm{PhD}$ thesis). Universite Bordeaux 1, Talence.

Rigaud, S., 2013. Les objets de Parure associes au depo^t funeraire mesolithique de GroBe Ofnet: implications pour la comprehension de l'organisation sociale des dernieres societes de chasseurs-cueilleurs du Jura Souabe. Anthropozoologica 48, 207 e230.

Rigaud, S., d' Errico, F., Vanhaeren, M., 2010. Los objetos de adorno personal asociados al esqueleto mesolítico Bran a-2. In: Vidal Encinas, J.M., Encina Prada Marco, M. (Eds.), Los Hombres Mesolíticos de La Cueva de La Bran a-Arintero (Valdeugueros, Leon). Museo de Leon, Leon, pp. $62 \mathrm{e} 81$.

Rigaud, S., d' Errico, F., Vanhaeren, M., Pen alber, X., 2014. A short-term, task-specific site: epipalaeolithic settlement patterns inferred from marine shells found at Praileaitz I (Basque Country, Spain). Journal of Archaeological Science 41, 666e678.

Sealy, J., 2006. Diet, mobility, and settlement pattern among Holocene HunterGatherers in Southernmost Africa. Current Anthropology 47, 569e595.

Simpson, B., 1996. Self and social identity: an analysis of the Mesolithic body adornment from the Scottish Western Isles. In: Pollard, T., Thomas, A. (Eds.), The Early Prehistory of Scotland. Edinburgh University Press, Edinburgh, pp. 237e251.

Sommer, R.S., Zachos, F.E., Street, M., Jo€ris, O., Skog, A., Benecke, N., 2008. Late Quaternary distribution dynamics and phylogeography of the red deer (Cervus elaphus) in Europe. Quaternary Science Reviews 27, 714e733.

Straus, L.G., 1979. Mesolithic adaptations along the northern coast of Spain. Quaternaria 21, $305 \mathrm{e} 327$.

Taborin, Y., 1993. Traces de façonnage et d'usage sur les coquillages perfores. In: Anderson, P., Beyries, S., Otte, M., Plisson, H. (Eds.), Traces et Fonction: Les Gestes Retrouves. ERAUL, Liege, pp. $255 \mathrm{e} 267$.

Taborin, Y., 1998. La parure en coquillage au Paleolithique. CNRS, Supplement of Gallia Prehistoire XXIX, Paris.

Thompson, V.D., Reynolds, M.D., Haley, B., Jefferies, R., Johnson, J.K., Humphries, L., 2004. The Sapelo shell ring complex: shallow geophysics on a Georgia Island. Southeastern Archaeology 23, $192 \mathrm{e} 201$.

Trussell, G.C., 2000. Phenotypic Clines, Plasticity, and morphological trade-offs in an intertidal snail. Evolution 54, 151e166.

Utrilla, P., 1996. La sistematizacion del Magdaleniense cantabrico: una revision historica de los datos. In: Moure Romanillo, A. (Ed.), El Hombre Fosil: 80 An os Despues, Homenaje a Hugo Obermaier. Universidad de Cantabria, Santander, pp. 211e247. 
Vanhaeren, M., 2002. Les fonctions de la parure au Paleolithique superieur: de l'individu a l'unite culturelle ( $\mathrm{PhD}$ thesis). Universite de Bordeaux 1, Bordeaux, Talence.

Vanhaeren, M., 2010. Les fonctions de la parure au Paleolithique superieur: de l'individu a l'unite culturelle. Editions Universitaires Europeennes, Sarrebruck.

Vanhaeren, M., d' Errico, F., 2003. Childhood in the Epipaleolithic. What do personal ornaments associated to burials tell us? In: Larsson, L., Kindgren, H., Knutsson, K. Leoffler, D., Åkerlund, A. (Eds.) Mesolithic on the Move, Oxford, pp. 494e505.

Vanhaeren, M., d’ Errico, F., van Niekerk, K.L., Henshilwood, C.S., Erasmus, R.M., 2013. Thinking strings: additional evidence for personal ornament use in the Middle Stone Age at Blombos Cave, South Africa. Journal of Human Evolution 64, 500e517.

Vidal, J.M., Fernandez, C., Prada, M., Fuertes, N., 2008. Los hombres Mesolíticos de la BranaArintero (Valdelugueros, $\mathrm{L}^{\sim}$ eon): un hallazgo funerario excepcional en la vertiente meridional de la Cordillera Cantabrica. In: Ramil Rego, E. (Ed.), Congreso Internacional de Arqueoloxía de Vilalba. 11e14 de Junio. Fervedes, Vilalba, Lugo, pp. 153e164.

Watson, D.C., Norton, T.A., 1987. The habitat and feeding preferences of Littorina obtusata (L.) and L. mariae sacchi et rastelli. Journal of Experimental Marine Biology and Ecology $112,61 \mathrm{e} 72$.

Wayward, P.J., Ryland, J.S., 1996. Handbook of the Marine Fauna of North-West Europe. Oxford University Press, Oxford.

White, E.M., Hannus, L.A., 1983. Chemical weathering of bone in archaeological Soils. American Antiquity 48, 316e 322 . 